\title{
Archaeometric study of a typical medieval fortified granary (Amtoudi Agadir, Anti-Atlas Chain, southern Morocco): a key case for the maintenance and restoration of historical monuments
}

\author{
Giuliana Raffaelli (1), Pedro Robles-Marín (2), Francesco Guerrera (1), Manuel Martín-Martín (3), \\ Francisco Javier Alcalá (4), (5), Maria Letizia Amadori (6), Lahcen Asebriy (7), \\ Iz-Eddine El Amrani El Hassani (7) \& Julian TeJera de LeÓn (7)
}

\section{ABSTRACT}

An interdisciplinary archaeometric study concerning the Amtoudi Agadir, declared World Cultural Heritage (northern border of the Sahara Desert, southern Morocco), was performed consisting in lithostratigraphic reconstruction of the bedrock, diagnosis of constitutive materials (stones, mortars, and wooden elements), and analyses of constructive techniques and architectonic elements (load-bearing and supported structural elements). The medieval agadir (fortified granary) was built directly on a rocky piton with rocks of the substratum with traditional materials and ancestral techniques. The stones have been identified and classified into four petrofacies. Degradation such as biological attacks, chromatic alteration, erosion, exfoliation, and fissuration on the stones have been characterized. Recommendations for conservation and maintenance of the rocks have been proposed in compatibility with the environment. Load-bearing (masonry walls) and supported structural elements (ceiling structures) have also been studied in order to define their stability. Worst cases of 1- and 2-height walls, together with worst cases of the wooden or stone ceiling structures have been analyzed. Materials, techniques, and dimensions have been characterized for possible failures to shearing, bending, and flexural buckling as guide for maintenance of the agadir. The main problems of the walls derive from excessively thin construction with a lack of interlocking of the rocks and a diminished proportion or quality of mortar joining the rocks due to washing. It has been recommended to avoid thicknesses lower than $0.4 \mathrm{~m}$ for 2-height walls and lower than $0.3 \mathrm{~m}$ for 1-height walls. A nominal load has been estimated in the worst case (with wooden elements) for the ceiling structures of about $7.0 \mathrm{KN} / \mathrm{m}^{2}$. The calculations have indicated that a $25 \%$ increase over the nominal load would imply a risk of failure, the use of stone elements being preferable over wooden ones. With these propositions for the Amtoudi Agadir, new management and prospects for cultural tourism are feasible.

(1) Dipartimento di Scienze della Terra, della Vita e dell'Ambiente (DiSTeVA), Università degli Studi di Urbino "Carlo Bo", Campus Scientifico "Enrico Mattei”, Via Cà Le Suore, 2/4 - 61029 Urbino, Italy.

(2) Departamento de Ingeniería Civil, Alicante University, AP-99, E-03080, Alicante, Spain. Esfera Consultores de la construcción, 30007 Murcia, Spain.

(3) Departamento de Ciencias de la Tierra y Medio Ambiente, Alicante University, AP-99, E-03080, Alicante, Spain. Corresponding author manuel.martin.m3@gmail.com

(4) Civil Engineering Research and Innovation for Sustainability (CERIS), Instituto Superior Técnico, University of Lisbon, 1049001 Lisbon, Portugal.

(5) Instituto de Ciencias Químicas Aplicadas, Facultad de Ingeniería, Universidad Autónoma de Chile, 7500138 Santiago, Chile.

(6) Dipartimento di Scienze di Base e Fondamenti (DiSBeF), Università degli Studi di Urbino "Carlo Bo", Piazza Rinascimento, 6 61029 Urbino, Italy.

(7) Département des Sciences de la Terre, Institut Scientifique, Université Mohammed V de Rabat, B.P.703, Rabat, Morocco.
KEY WORDs: Amtoudi Agadir, Morocco, constructive techniques, deterioration processes, conservation measures, sustainable maintenance.

\section{INTRODUCTION AND AIMS}

On the southern border of the Anti-Atlas Chain (northern Sahara Desert domain), the legacy of the millenary culture of the southern Moroccan population has survived until today in the form of agadirs (NAJI, 2003). Agadirs are typical fortified citadel and granary, testimony of the birth of the nation of Morocco, dating from the tenth century in some cases, positioned on rocky promontories to protect crops and livestock of the community from sudden attacks. They are located in inhabited areas with permanent water and food supply such as oases (AlCALÁ et alii, 2015). In the study case an oasis is also present related to the Wadi des Argans where the Amtoudi village is seated. They were built with different architectural techniques and located directly on the bedrock, which supplied geomaterials for building, thus making them indistinguishable from the landscape when viewed from afar. Due to their defensive character, agadirs were positioned in inaccessible sites with unstable vertical cliffs that posed potential geological hazard.

Because of the great importance of these cultural heritage buildings, as well as to maintain the tourist attractions for the local economy, surveys for geological-risk assessment are needed to design sustainable conservation policies. Many agadirs of the southern Morocco are currently abandoned due to the modern lifestyle and the exodus of the rural population, while others persist due to the tourism attracted by the historical legacy and desert landscapes. This is the case of the Amtoudi Agadir (fig. 1), a World Cultural Heritage expression of the ancient Moroccan culture on the northern border of the Sahara Desert in southern Morocco. Living cultural heritage is related to the nature of constituent materials and alteration processes caused by environmental forces, both of anthropic and natural origin. The weathering processes endure fast accelerations if the factors related to abandonment, lack of maintenance, and wrong conservation treatments are added to the normal ageing processes. Today, the decay process is a natural phenomenon that cannot be arrested, and therefore it is important to document the object and its historical importance. Moreover, some stu- 

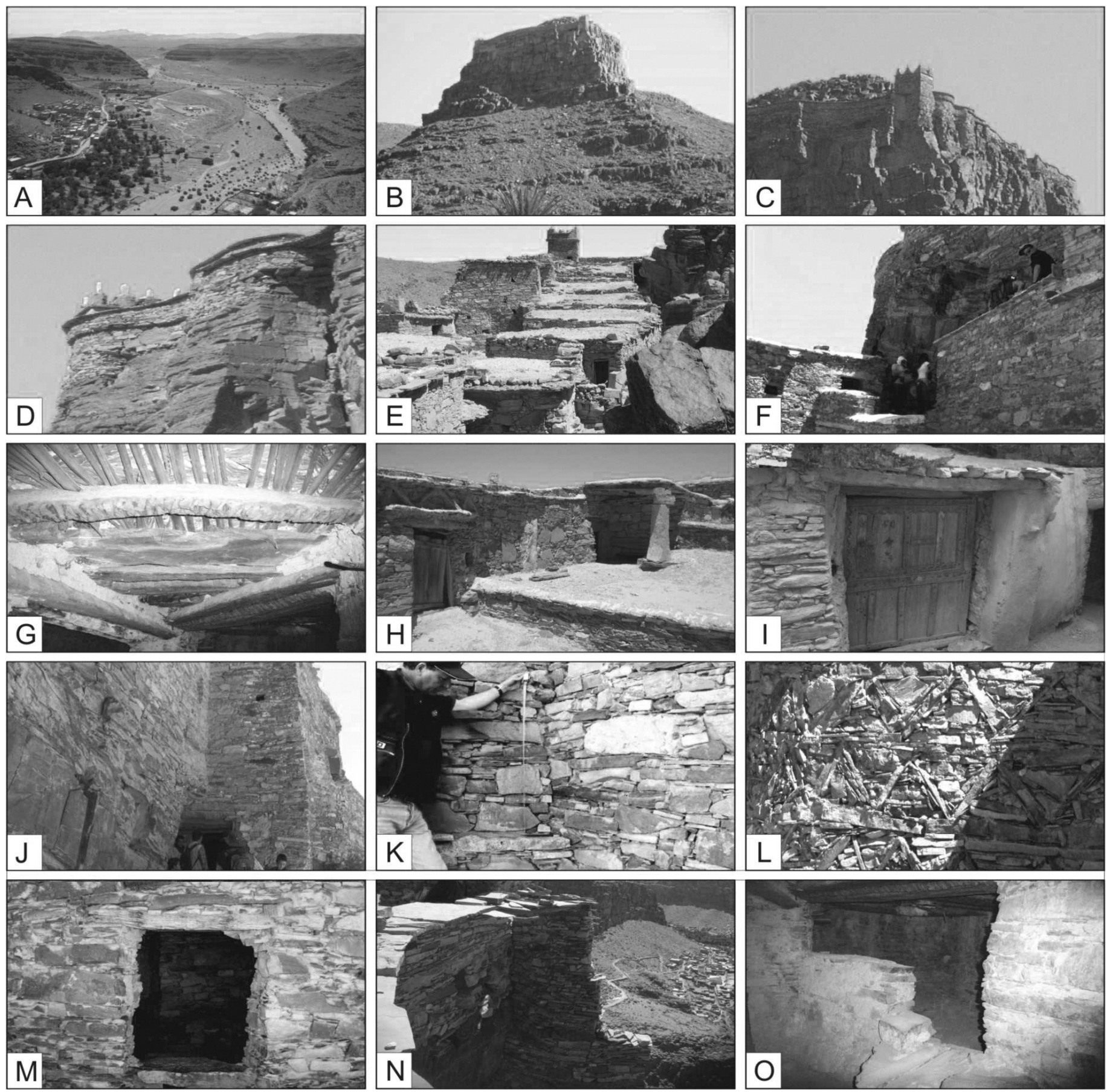

Fig. 1 - Photographic documentation of the Amtoudi Agadir (Anti-Atlas Chain, southern Morocco): A) view from the agadir showing the Amtoudi Village and Oasis; $B$ ) south-western view of the agadir from the Amtoudi Village; $C$ ) and $D$ ) some particular views of the peripheral wall of the agadir; $E$ ) and $F$ ), the internal aspect of the agadir; $G$ ) supported structural wooden elements: palm joists and beams with leaves; $H$ ) internal walls showing carpentry elements such as lintels and doors, and an isolated monolithic stone pillar; $I$ ) olive-door carpentry element; $J$ ) exterior wall anchored to the irregular bedrock; $K$ ) wall with interlocking of horizontal stones; $L$ ) wall with mixed horizontal-oblique interlocking of stones; $M$ ) wall with mortar as binder; $N$ ) exterior wall with a buttress; $O$ ) internal walls and pier sustaining the ceiling structure of enclosed space.

dies on materials (AMADORI et alii, 1989; GORGONI et alii, 1993) and consequential environmental features, may make it possible for the decay to be delayed, decreasing the degradation (BERNARDI, 2003). This enables a longer fruition of the same cultural heritage, both as cultural fund and for the value related to its artistic contents.

Until today the only study regarding the medieval Amtoudi Agadir was performed recently by same authors, dealing with the geological risk of this site (RoBLEsMARín et alii, 2015), including a complete geological evaluation of the area to deduce the influence of tectonic activity, gravitational processes (landsliding, screes, and fallen blocks), halokinetic processes (collapses and bulging), hydrological processes (flooding and erosion), degradation evidence, and conservation measures. Therefore this study represents the first archaeometric eva- 
luation to recognize the state of conservation of construction materials and architectonic elements as well as the vulnerability particular to this site, examining (1) the lithostratigraphy of the bedrock, (2) the constitutive materials (stones, mortars, and wooden elements), and (3) the constructive techniques and the architectonic elements (gravity and load-bearing walls, ceiling structures, pillars, lintels, buttresses, etc.).

In the conservation project of the Amtoudi Agadir, the scientific approach to combat the complex deterioration causes, was firstly developed through (1) a historical study of the site, (2) the nature and the materials composing the buildings in Amtoudi area, and (3) the evaluation of the different types of decay in terms of distribution and intensity factors. Finally, global geological and environmental features surrounding the historical building were determined, and the factors affecting the structure were evaluated. It was also possible to identify the key steps for restoring, and maintaining, and improving the care of the site, with the aim of protecting and increasing the cultural value of these kinds of archaeological sites.

\section{METHODOLOGY, MATERIALS, AND SAMPLINGS}

The archaeometric study of the Amtoudi Agadir involved the characterization of used materials, of construction techniques, of architectural elements, and of the causes for deterioration as well as the technical proposal for sustainable conservation and evaluation. Some regional works were initially programmed. A detailed geological mapping of the Amtoudi area was performed to identify the areal distribution of lithostratigraphic intervals, rocks, and tectonic structures. The study of the bedrock was focused on identifying the materials used for the construction and maintenance of the agadir. Weather characteristics such as precipitation, temperature regimes, and atmospheric chemistry were investigated to understand the mineral degradation of the stones. The analysis of the materials was then focused on stones, mortars, and wooden elements used for constructing the Amtoudi Agadir. In relation to the ancestral construction techniques and architectonic elements classified, the study was focused on the walls and the ceiling structures.

a) Field analysis (geological survey and mapping, lithostratigraphic reconstruction of the bedrock succession, identification of the lithotypes, and sampling) was performed on geomaterials cropping out in the surroundings of the agadir as source of the building stones and other raw materials. Fifteen samples of rocks were taken from this local succession $(1,2,3 \mathrm{~A}$ to $3 \mathrm{C}, 4$ to $8,9 \mathrm{~A}, 9 \mathrm{~B}$, 10 , and 11$)$, and ten samples (P-01 to P-10) were collected from stones used in the agadir (tab. 1, fig. 2). A petrographic study of thin sections was performed to determine the nature and the texture of stones, using a polarizing light microscope Nikon, Model TK-1270E. The results were compared with those from the same analyses of stones employed in the masonry of the agadir. X-ray powder diffraction (XRD) analyses using a Philips PW 1830, $\mathrm{Cu} \mathrm{K \alpha /Ni,} 35 \mathrm{Kv}, 30 \mathrm{~mA}$ diffractometer were carried out to characterize bulk mineralogy of samples. Wholerock analyses were carried out by means fusion XRF spectrometry (FUS-XRF) to complete the characterization of field rocks. Major elements were determined on
TABLE 1

Stone samples collected in the field and in the Agadir of Amtoudi: agadir samples are located in fig. 2 and field samples are located in the column of fig. 4 .

\begin{tabular}{|c|c|c|c|}
\hline \multicolumn{2}{|c|}{ Samples } & Description & Location \\
\hline \multirow{17}{*}{$\begin{array}{l}v \\
0 \\
\text { 㸓 }\end{array}$} & 1 & Limestone & Interval D \\
\hline & 2 & Sandstone & Interval D \\
\hline & $\mathbf{3 A}$ & Claystone/Siltstone & Interval B \\
\hline & 3B & Claystone/Siltstone & Interval B \\
\hline & $3 \mathrm{C}$ & Claystone/Siltstone & Interval D \\
\hline & 4 & Limestone & Interval D \\
\hline & 5 & Sandstone & Interval D \\
\hline & 6 & Schist & Interval D \\
\hline & 7 & Quartz-arenite & Interval B \\
\hline & 8 & Limestone & Interval B \\
\hline & 9A & Limestone & Interval B \\
\hline & 9B & Sandstone & Interval C \\
\hline & 10 & Tuff & Interval B \\
\hline & 11 & Limestone & Interval A \\
\hline & 12 & Limestone & Interval A \\
\hline & M-10 & ground rich in clays & Interval B \\
\hline & M-12 & ground rich in clays & Interval B \\
\hline \multirow{10}{*}{ 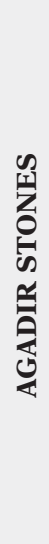 } & P-01 & arkosic sandstone & Inside SW Tower \\
\hline & P-02 & claystone/silstone & Frontage SW Tower (left side) \\
\hline & P-03 & arkosic sandstone & Frontage SW Tower (right side) \\
\hline & P-04 & wackestone/grainstone & Frontage SW Tower (right side) \\
\hline & P-05 & wackestone/grainstone & Frontage SW Tower (right side) \\
\hline & P-06 & claystone/silstone & Frontage SW Tower (right side) \\
\hline & P-07 & claystone/silstone & Building near SW Tower \\
\hline & P-08 & claystone/silstone & $\begin{array}{l}\text { Beehive-like building } \\
\text { near the SW Tower }\end{array}$ \\
\hline & P-09 & schist & $\begin{array}{l}\text { Basement outcropping } \\
\text { near the SW Tower }\end{array}$ \\
\hline & P-10 & schist & $\begin{array}{c}\text { Basement outcropping } \\
\text { near the SW Tower }\end{array}$ \\
\hline
\end{tabular}

samples fused with lithium metaborate/tetraborate in platinum crucibles and glass discs analysed by XRF.

b) Walls usually consisted of an imbrication of stones but in some case the stones were interlocked using a mortar as binder. Mortars are made of soil rich in clays and poor in a rough lime. Two samples (M-10 and M-12; tab. 1) of material used as mortar were collected near of the agadir to be tested in the geotechnical laboratory EUP from the University of Alicante. Tests for sieve gradation grain size (UNE 103.101/95 norm), for sediment grain size (UNE 103.102/95 norm), and for Atterberg limits (i.e. liquid, plastic and plasticity index; UNE 103.103/94 and UNE 104.102/93 norms) were performed on the samples.

c) Wooden elements used for ceiling structures, lintels, and carpentry in the agadir usually came from argan, palm, and olive trees. The study consisted of compiling an inventory, recording dimensions, and evaluating the state of conservation. Problems affecting elements were studied and solutions were proposed. 
TABLE 2

Samples analysed from walls and ceiling structures of the Amtoudi Agadir.

\begin{tabular}{|c|c|c|c|}
\hline \multicolumn{2}{|c|}{ Samples } & Description & Location \\
\hline \multirow{27}{*}{ 通 } & $\mathrm{W}-01$ & Two-height exterior wall & Frontage of the entrance \\
\hline & W-02 & Two-height interior wall & Buildings near the entrance \\
\hline & W-03 & One-height interior wall & $\begin{array}{l}\text { Buildings on the west side } \\
\text { of the agadir }\end{array}$ \\
\hline & W-04 & Two-height interior wall & Eastern wall of the SW Tower \\
\hline & W-05 & Two-height interior wall & $\begin{array}{c}\text { Buildings on the south-west side } \\
\text { of the agadir }\end{array}$ \\
\hline & W-06 & One-height interior wall & $\begin{array}{l}\text { Buildings on the west side } \\
\text { of the agadir }\end{array}$ \\
\hline & W-07 & One-height interior wall & Buildings near the entrance \\
\hline & W-08 & One-height interior wall & $\begin{array}{l}\text { Buildings on the west side } \\
\text { of the agadir }\end{array}$ \\
\hline & W-09 & Two-height interior wall & $\begin{array}{l}\text { Buildings on the west side } \\
\text { of the agadir }\end{array}$ \\
\hline & $\mathrm{W}-10$ & One-height interior wall & $\begin{array}{l}\text { Buildings on the west side } \\
\text { of the agadir }\end{array}$ \\
\hline & $\mathrm{W}-11$ & One-height interior wall & $\begin{array}{l}\text { Group of buildings on the central } \\
\text { part of the agadir }\end{array}$ \\
\hline & $\mathrm{W}-12$ & One-height interior wall & $\begin{array}{l}\text { Buildings on the east side } \\
\text { of the agadir }\end{array}$ \\
\hline & W-13 & One-height interior wall & $\begin{array}{l}\text { Group of buildings on the central } \\
\text { part of the agadir }\end{array}$ \\
\hline & $\mathrm{W}-14$ & One-height interior wall & $\begin{array}{c}\text { Buildings on the north-west side } \\
\text { of the agadir }\end{array}$ \\
\hline & $\mathrm{W}-15$ & Two-height interior wall & Northern wall of the SE Tower \\
\hline & $\mathrm{W}-16$ & Two-height interior wall & Western wall of the SE Tower \\
\hline & $\mathrm{W}-17$ & Two-height interior wall & Southern wall of the NE Tower \\
\hline & $\mathrm{W}-18$ & Two-height interior wall & $\begin{array}{l}\text { Buildings on the north-west side } \\
\text { of the agadir }\end{array}$ \\
\hline & W-19 & Two-height interior wall & Eastern wall of the SW Tower \\
\hline & $\mathrm{W}-20$ & One-height interior wall & $\begin{array}{c}\text { Wall on the east side of the agadir } \\
\text { (hives) }\end{array}$ \\
\hline & $\mathrm{W}-21$ & One-height interior wall & $\begin{array}{c}\text { Wall on the east side of the agadir } \\
\text { (hives) }\end{array}$ \\
\hline & $\mathrm{W}-22$ & One-height interior wall & $\begin{array}{l}\text { Buildings near the entrance } \\
\text { (repaired) }\end{array}$ \\
\hline & $\mathrm{W}-23$ & One-height interior wall & $\begin{array}{l}\text { Buildings on the south-west side } \\
\text { of the agadir (repaired) }\end{array}$ \\
\hline & $\mathrm{W}-24$ & One-height interior wall & Frontage near the entrance \\
\hline & $\mathrm{W}-25$ & One-height interior wall & Frontage close to the SE Tower \\
\hline & $\mathrm{W}-26$ & One-height interior wall & $\begin{array}{c}\text { Western exterior wall close } \\
\text { the SW Tower }\end{array}$ \\
\hline & $\mathrm{W}-27$ & One-height interior wall & Exterior wall close to the entrance \\
\hline \multirow{10}{*}{ 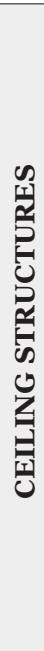 } & C-01 & Stone ceiling structure & SE Tower \\
\hline & $\mathrm{C}-02$ & Stone ceiling structure & $\begin{array}{l}\text { Buildingson the west side } \\
\text { of the agadir }\end{array}$ \\
\hline & C-03 & Stone ceiling structure & $\begin{array}{l}\text { Buildings on the west side } \\
\text { of the agadir }\end{array}$ \\
\hline & C-04 & Stone ceiling structure & $\begin{array}{l}\text { Buildings on the west side } \\
\text { of the agadir with stone slabs }\end{array}$ \\
\hline & $\mathrm{C}-05$ & Wooden ceiling structure & $\begin{array}{l}\text { Buildings on the west side } \\
\text { of the agadir with palm leaf }\end{array}$ \\
\hline & $\mathrm{C}-06$ & Wooden ceiling structure & $\begin{array}{c}\text { Buildings on the west side } \\
\text { of the agadir with bended joist }\end{array}$ \\
\hline & C-07 & Wooden ceiling structure & $\begin{array}{l}\text { Building close the entrance } \\
\text { with broken argan joist }\end{array}$ \\
\hline & C-08 & Stone ceiling structure & $\begin{array}{l}\text { Buildings on the west side of the } \\
\text { agadir with broken stone joist }\end{array}$ \\
\hline & C-09 & Wooden ceiling structure & $\begin{array}{l}\text { Buildings on the west side of the } \\
\text { agadir with broken argan joist }\end{array}$ \\
\hline & $\mathrm{C}-10$ & Wooden ceiling structure & $\begin{array}{l}\text { Building close the entrance } \\
\text { with broken argan joist }\end{array}$ \\
\hline
\end{tabular}

d) Walls were studied in 27 sections in Amtoudi Agadir (W-01 to W-27) in two steps (tab. 2; fig. 2). The first step involved the calculation of the ratio of voids among stones in the wall (voids ratio hereafter), as in THORNBUSH \& Viles (2008), THORNBUSH $(2013,2014)$, and references therein. Image processing of digital photographs was used for the voids ratio, as in BANTA et alii (2003), FERNLUND (2005), KUMARA et alii (2012), and references therein, by using digital photos and standard software of image processing to establish a black-white spectrum (THORNBUSH, 2013, 2014), where the white colour identifies stones and black the voids. The voids ratio was scaled from 0 to 1 , where 0 represents voids and 1 the stones. Values between 0 and 1 are related with the specific weight of the mortar since the specific weight of stones and mortars were tested in the laboratory. The stability of stone walls directly depends on the geometric characteristic and their specific weight but in the case of "gravity walls", according to the mechanical principles, stability was directly proportional to the specific weight (weight per unit length) since the stability increases when the specific weight increases. Therefore, the method developed to determine the specific weight by using image processing of digital photographs of walls, provided a semi-quantitative approach to quickly estimate the stability of large areas of walls.

The second step consisted of calculating the security of the walls mainly for the worst case (flexural buckling), since the geotechnical characteristics of the bedrock of the site were classified as "very good quality" (ROBLES-MARíN et alii, 2015). The calculations performed for wall resistance of the Amtoudi Agadir were made following standard procedures according to European criteria (Spanish legislation). Especially, the Technical Building Code DB SE-AE and SE-F (BOE, 2006) was followed. For this purpose, the resistance of the rocks was determined by laboratory testing, as indicated above, but the mortar strength was unknown and was considered as a variable for calculations. The specific weights introduced in calculations ranged from 16 to $24 \mathrm{kN} / \mathrm{m}^{3}$ and estimations were performed for 2-height bridged masonry walls and for one-height free (unbridged) masonry walls, since these were the common and worst-case typologies in the Amtoudi Agadir. In the case of load-bearing masonry walls, $7 \mathrm{kN} / \mathrm{m}^{2}$ of overload was considered (ROBLES-MARín et alii, 2015).

e) The ceiling structures were characterized by calculating the nominal load, including its own weight and overloads by the study of 10 cases (C-01 to C-10; tab. 2; fig. 2). For this, rocks were sampled for testing in the Cehegin Marble Technologic Center Laboratory (Murcia, Spain) and the Ground Engineering Laboratory from University of Alicante (Alicante, Spain). The analyses consisted of 10 samples for the uniaxial compression-resistance test (s/UNE 22950-1), 12 samples for rock porosity (s/UNE 22950-5) and 31 samples for specific weight (s/UNE-EN 1936). The maximum traction and compression due to bending of the joists, as well as the maximum shear stress at the supports were determined using standard procedures (GERE, 2004).

\section{GEOLOGICAL FRAMEWORK}

The Amtoudi region studied belongs to the western Anti-Atlas Chain (Morocco) and it is located between the northern portion of the West African Craton (WAC), the 


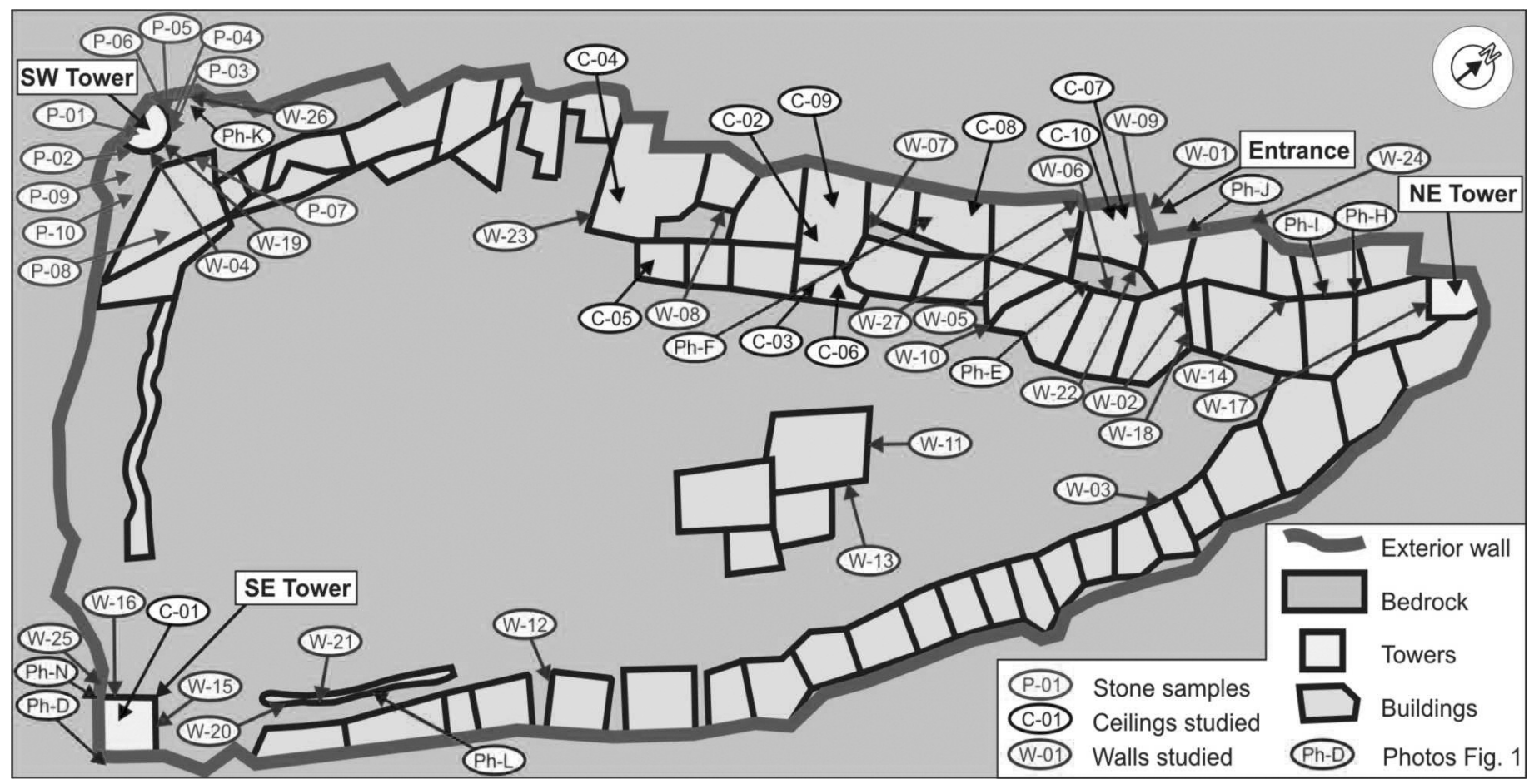

Fig. 2 - Sketch of the Amtoudi Agadir plan with location of the buildings, towers, collected stone samples, studied walls, and ceilings elements.

High Atlas Chain to the north, and the Tindouf Basin to the south in the Guelmim region (fig. 3A). This chain, which appears as a huge anticlinorium oriented SW-NE is part of the Appalachian-Ouachita-Mauritanides orogenic belt (GASQUET et alii, 2008; with bibl.) derived from Appalachian orogeny and poorly affected by Alpine deformation. Schematically, it is represented by two main different successions:

(i) A pre-Palaeozoic basement constituted by a set of metamorphic and sedimentary rocks marked by a complex geologic and tectonic evolution, showing a stratigraphic succession divided by major discontinuities (ENNIH \& LIÉGEOIS, 2001; BURKHARD et alii, 2006; SOULAIMANI \& BURCKARD, 2008; among others) cropping out as typical inliers emerging in depressed areas.

(ii) An unconformable (CHOUBERT, 1963; NAIDOO et alii, 1991; ENNIH \& LIÉGEOIS, 2001) lower-middle Cambrian transgressive sedimentary cover dominated by shallow detritic marine and carbonates deposits. The Devonian sedimentation becomes carbonatic, indicating the end of the detritic supply coming from the Saharan bouclier. The late Devonian tectonic regime (Hercynian orogeny) changes from the extensive (up to the early Palaeozoic) to compressive that extends to the Permian.

The thickness of the Palaeozoic stratigraphic record may exceed $10 \mathrm{~km}$ in the westernmost Anti-Atlas (Tiznit region) but can be less than $5-6 \mathrm{~km}$ in the easternmost Anti-Atlas (Tafilalt region) (BURCKARD et alii, 2006; SoULAIMANI \& BURCKARD, 2008). The lower Palaeozoic stratigraphic record is documented pointing out the presence of limestone rocks at the base of the transgression and thus mark the beginning of the new sedimentary cycle. After the carbonates, the sedimentation becomes detritic overall, forming arenitic and clayey formations with rich fauna, indicating low depth of the sedimentation corre- sponding to a stable marine platform. This platform extends into north-western domain of the $W A C$, where its large portions are progressively covered by transgressive deposits. The Cambrian sedimentary cover is gently folded and shows a low degree of metamorphism without major detachments or thrust faults, making the Anti-Atlas a usual (intra-cratonic) type of belt that does not closely fit classic orogeny.

The main tectonic deformation of the Amtoudi study area is characterized mainly by (i) folds affecting the entire sedimentary pile coverage from Adoudounien to the upper Devonian; and (ii) normal slip faults trending generally between $\mathrm{N} 120^{\circ} \mathrm{E}, 80^{\circ} \mathrm{NNE}$, and $\mathrm{N} 145^{\circ} \mathrm{E}, 80^{\circ}$ vertical compatible compression NW-SE. In particular, folds trending NE-SW and sub-horizontal axes or slightly dipping to the SW or NE of the pre-Cambrian basement mark the deformation of the Cambrian sedimentary suite. It adapts to the vertical and lateral spread of tectonic stresses during lifting and remobilization of the different blocks of the base.

Structurally, the evolution of the Anti-Atlas Chain is controlled mainly by the pre-Cambrian tectonic structures of the basement derived from Proterozoic polyphase tectonics. Two major phases of deformation mark the Palaeozoic tectonic history of the western Anti-Atlas (Soulaimani, 1998) within the Hercynian orogenesis. The short thermal Carboniferous event dated by fission tracks on zircons from the pre-Cambrian basement, followed by rapid cooling (SEBTI et alii, 2009), supports an attribution to Hercynian (orogeny) folding followed by erosional exhumation. The shortening is also shown by the soft folding of the cover involving also the basement with a direction that changed over time from NW-SE to N-S.

The main geological characters of the study area are depicted in fig. 3B (map and section) and in fig. 3C (local reconstructed stratigraphic succession). 


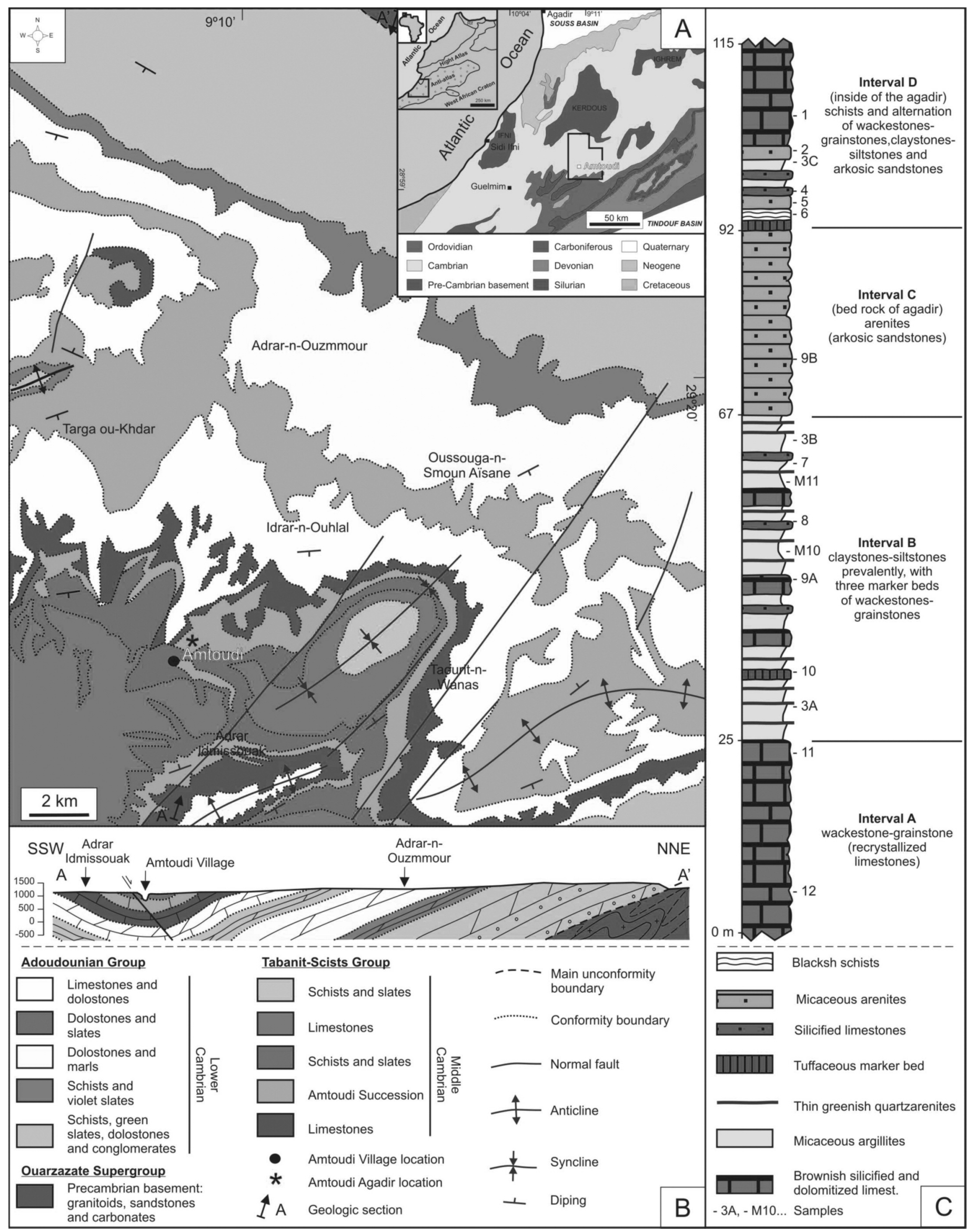

Fig. 3 - A) sketch map of the western Anti-Atlas Chain and location of the study area; $B$ ) detailed geological map and section of the study area; $C)$ lithostratigraphic column with intervals of the reconstructed local Amtoudi Succession. 


\section{ATMOSPHERIC ENVIRONMENT}

Daily precipitation and temperature regimes, as well as the atmospheric chemistry are driving forces controlling the physicochemical processes for mineral degradation of stones in terrestrial mid-latitudes (LA IGLESIA et alii, 1994), even in rural environments (MATOvíc et alii, 2014). Large amplitudes in daily precipitation and temperature in drylands are documented to produce mineral degradation due to physical processes, while the rainfall mineralization and acidification can be assumed as the main forces for chemical alterations (COOKE, 1979; BRADLEY \& Middleton, 1988; CAMufFo, 1992).

In terms of climate, the study area is dry subtropical with a bimodal precipitation distribution (ESPER et alii, 2007). Most of the precipitation (P) occurs erratically during autumn and spring. Extreme rainfall events around $50 \mathrm{~mm}$ per day have been documented. In winter, cold northern winds predominate, while dry easterly winds occur in summer (BorN et alii, 2008). Annual mean $\mathrm{P}$ is around $125 \mathrm{~mm}$ with a coefficient of variation of 0.45 over the period 1973-2011. Annual mean temperature is around $19.5^{\circ} \mathrm{C}$, with the minimum in January and maximum in August; the daily amplitude may be as high as $30^{\circ} \mathrm{C}$. Insolation is high, with more than $3,500 \mathrm{~h}$ per year in low-lying places. The annual mean potential evapotranspiration (EP) is around $1,500 \mathrm{~mm}$. The mean daily $\mathrm{EP}: \mathrm{P}$ ratio is around 0.2 , ranging from 0.1 in summer dry season to 0.3 in spring wet season; these values are indicative of arid climatic conditions (ARORA, 2002).

Regarding the atmospheric chemistry, this is a rare piece of information in sparse-data drylands. Atmospheric chemistry includes both the saline content from wet deposition from rainfall as well as the dry deposition from airborne dust (AlCALÁ et alii, 2011; AlCALÁ \& CUSTOdIO, 2015). Over the period April 2009 to April 2011, atmospheric chemical bulk deposition in Amtoudi village $\left(29^{\circ} 14^{\prime} 50^{\prime \prime} \mathrm{N}, 9^{\circ} 11^{\prime} 44^{\prime \prime} \mathrm{W}, 849 \mathrm{~m}\right.$ a.s.l.) was neutral due to the prevalence of soluble continental dust, and slight acid in some spurious wetter periods due to incoming diluted cloud fronts from Atlantic Ocean (AlcAlá et alii, 2015). The non-marine deposition fraction $\left(23 \mathrm{~g} \mathrm{~m}^{-2}\right.$ year-1) was around $94 \%$ of the chemical bulk deposition (Alcalá et alii, 2015); it was characterized by high contents of $\mathrm{HCO}_{3}$, $\mathrm{SO}_{4}^{\bar{y}}$, and $\mathrm{SiO}_{2}$, presumably associated with wind-blown particles from lithology. Quartz, calcite, and feldspars dominate the mineral contents of airborne dust with a minor clay fraction composed by kaolinite and illite (KHIRI et alii, 2004).

\section{RESULTS}

\section{LITHOSTRATIGRAPHY}

Field observations consisting of the geological survey and mapping of the study area and surroundings, detailed lithostratigraphic analysis of the bedrock succession, identification and sampling of main lithotypes (figs. 3B, 3C), and later petrographic examinations (on brownish recrystallized limestones, darkish micaceous argillites, laminated arenites, and blackish and purple stratified schist: see later tab. 3; fig. 4) confirm the attribution to the middle Cambrian over the Adoudounian Group (SouLAIMANI \& BURCKARD, 2008). The lithofacies indicate a shelf deposition with additional fine detritic supply coming from Saharan domain, as reported by BURCKARD et alii (2006). The study area is affected by intense spaced fractures grouped in three main sub-vertical jointing systems oriented $\mathrm{N} 150^{\circ}, \mathrm{N} 100^{\circ}$, and between N-S and $\mathrm{N} 20^{\circ}$. Small normal faults (shift around $50 \mathrm{~cm}$ ) with $\mathrm{N} 140^{\circ}$ direction are also present. Structurally, the succession belongs to the southern flank of a syncline included between two anticlines showing an axial direction approximately $\mathrm{N} 70^{\circ}$.

On the basis of previous results (ROBLES-MARÍN et alii, 2015) a detailed lithostratigraphic analysis of the local succession $\left(12^{\circ}\right.$ dipping toward $\left.213^{\circ}\right)$ led us to subdivide it into four main stratigraphic intervals that are characterized by different litho-petrofacies associations (fig. 3C).

Interval $A$, constitutes the lowest portion of local succession with a thicknesses of over $25 \mathrm{~m}$ and is dominant in the Amtoudi area. It consists of brownish recrystallized limestones (wackestone/grainstone) characterized by massive, detritic, silicified, dolomitized limestones with lamination, asymmetric ripples and irregular stratification; thickness is between 0.1 to $1.5 \mathrm{~m}$. Colour variations appear, corresponding to size changes (from very fine to sandy) of grains.

Interval $B$, predominantly claystone/siltstone, is characterized by darkish micaceous argillites, stratified, laminated, and silicified with massive dark-brownish arenites and siltstone interbedded. Three clearly distinguishable beds of wackestone/grainstone and some thin beds of very fine to coarser grey-green quartzarenites and of homogeneous silicified limestones are also present. Interval thickness is about $55 \mathrm{~m}$.

Interval $C$, immediately crops out under the agadir, constituting its geologic foundation. It consists of laminated arenites (arkosic sandstone) showing a bed varying from 1.0 to $1.5 \mathrm{~m}$ thick. These arenites are greyish-greenish in colour, from massive to thinly stratified, very finegrained and often covered with a black patina: they show great hardness. Laminated beds with chaotic, heterogeneous whitish pelites are also interbedded. The interval thickness is about $25 \mathrm{~m}$. Fe-Mn mineralizations and glauconie have been observed.

Interval $D$, is prevalently detected inside of the agadir for a thickness over $12 \mathrm{~m}$. It starts with blackish and purple stratified schist, with schistosity evidenced by the diffusion of the brightest mica flakes, fine-grained, and centimetric in thickness; pyrite is quite common. This is followed by an alternation of previous petrofacies as: wackestone/grainstone, claystone/siltstone and arkosic sandstone.

\section{AMTOUdi AgADIR AND BEDROCK MATERIALS}

Stones, mortars, and wooden elements, as well as natural rocks and materials from the bedrock used for the construction of the agadir were investigated with a multidisciplinary approach. Four types of petrographic facies were recognized in the samples from the bedrock succession outcropping in the agadir (fig. 3C; tab. 1) after optical analyses: Petrofacies 1: limestones (wackstone/grainstone), Petrofacies 2: claystone/siltstone, Petrofacies 3: arenites (arkosic sandstone), Petrofacies 4: schist. The mineralogical phases of all the examined samples (from field and agadir) are listed in tab. 3. Tab. 3 shows the results of the minera- 


\section{TABLE 3}

Semi-quantitative mineralogy from field and Amtoudi Agadir samples. Abbreviations and symbols. Qtz = Quartz; $\mathrm{Cal}=$ Calcite; Dol = Dolomite; Plg = Plagioclase; K-fs = K-Feldspar; Chl = Chlorite; Ill/Mic = Illite/Mica; Px = Pyroxenes; Hem = Hematite. $\mathrm{xxxx}=$ predominant phase; $\mathrm{xxx}=$ very abundant; $\mathrm{xx}=$ abundant; $\mathrm{x}=$ low abundant; = rare; $\operatorname{tr}=$ traces; $-=$ not detected.

\begin{tabular}{|c|c|c|c|c|c|c|c|c|c|c|}
\hline \multicolumn{2}{|c|}{ Samples } & Qtz & Cal & Dol & $\mathrm{Plg}$ & $K-F s$ & Chl & Ill/Mic & $P x$ & $\mathrm{Hem}$ \\
\hline \multirow{7}{*}{ 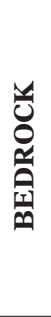 } & 1 & $\mathrm{x}$ & $\mathrm{xx}$ & $\mathrm{x}$ & $\mathrm{xx}$ & $\mathrm{x}$ & - & \pm & $\operatorname{tr}$ & - \\
\hline & $9 \mathrm{~A}$ & \pm & $\operatorname{xxxx}$ & - & $\mathrm{xxx}$ & $\mathrm{x}$ & \pm & \pm & - & $\operatorname{tr}$ \\
\hline & $3 \mathrm{~A}$ & $\mathrm{x}$ & $\mathrm{x}$ & - & $\mathrm{x}$ & \pm & $\mathrm{xx}$ & $\mathrm{x}$ & - & $\operatorname{tr}$ \\
\hline & $3 \mathrm{~B}$ & $\mathrm{x}$ & $\operatorname{tr}$ & - & $\mathrm{xxx}$ & $x$ & $\mathrm{xxx}$ & $\mathrm{xxx}$ & - & $\operatorname{tr}$ \\
\hline & 5 & $\mathrm{xx}$ & \pm & $\operatorname{tr}$ & $\mathrm{xxx}$ & $\mathrm{x}$ & $\mathrm{x}$ & $\mathrm{x}$ & $\operatorname{tr}$ & $\mathrm{tr}$ \\
\hline & $9 B$ & $\mathrm{xx}$ & $\operatorname{tr}$ & - & $\mathrm{xxx}$ & $\mathrm{x}$ & \pm & \pm & - & $\operatorname{tr}$ \\
\hline & 6 & $\mathrm{xx}$ & - & - & $\mathrm{xx}$ & $\mathrm{x}$ & $\mathrm{x}$ & $\mathrm{xx}$ & - & - \\
\hline \multirow{8}{*}{ 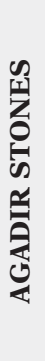 } & P-01 & $\mathrm{xx}$ & $\operatorname{tr}$ & \pm & $\mathrm{xxx}$ & $\mathrm{x}$ & $\mathrm{xxx}$ & $\mathrm{xxx}$ & \pm & - \\
\hline & $\mathrm{P}-02$ & $\mathrm{x}$ & \pm & \pm & $\mathrm{xxx}$ & $\mathrm{xx}$ & $\mathrm{xx}$ & $\mathrm{xx}$ & $\operatorname{tr}$ & tr \\
\hline & $\mathrm{P}-03$ & $\mathrm{xx}$ & - & \pm & $\mathrm{xxx}$ & $\mathrm{xx}$ & $\mathrm{xx}$ & $\mathrm{xx}$ & \pm & - \\
\hline & P-04 & $\mathrm{x}$ & $\mathrm{xxxx}$ & - & $\mathrm{xxx}$ & $\mathrm{xx}$ & $\operatorname{tr}$ & $\mathrm{x}$ & $\operatorname{tr}$ & - \\
\hline & $\mathrm{P}-05$ & $\mathrm{x}$ & $\mathrm{xxxx}$ & $\mathrm{x}$ & $\mathrm{xx}$ & $\mathrm{x}$ & - & $\mathrm{x}$ & $\operatorname{tr}$ & - \\
\hline & P-06 & $\mathrm{x}$ & $\mathrm{x}$ & $\operatorname{tr}$ & $\mathrm{xx}$ & \pm & \pm & $\mathrm{x}$ & $\operatorname{tr}$ & $\operatorname{tr}$ \\
\hline & $\mathrm{P}-07$ & $\mathrm{x}$ & $\mathrm{x}$ & $\operatorname{tr}$ & $\mathrm{xx}$ & $\mathrm{x}$ & $\mathrm{xx}$ & $\mathrm{xx}$ & $\operatorname{tr}$ & - \\
\hline & P-08 & $\mathrm{x}$ & $\mathrm{x}$ & - & $\mathrm{xxx}$ & $\mathrm{xx}$ & tr & $\mathrm{x}$ & $\mathrm{x}$ & - \\
\hline
\end{tabular}

logical analysis performed in a selection of the most representative and noteworthy samples appearing in the tab. 1 (samples 1, 9A, 3A, 3B, 5, 9B, and 6 from the bedrock; and samples P-01 to P-08 from the agadir stones).

Petrofacies 1: Wackstone/grainstone (samples 1, 4, 8, 9A, 11, and 12) are the dominant facies. They macroscopically appear banded with alternating brownish and greyish levels. Colour variations correspond to compositional changes and particle size. Under the microscope, the banded levels show a sharp petrographic variation ranging from very fine-grained carbonates (sometimes dolomitized; brownish band) to levels richer in quartz and feldspars grains and traces of carbonates (gray band). The level variations are often marked by enrichment in deformed and iso-oriented mica flakes. Some samples show recrystallization phenomena which occur with a neomorphism of the aggrading type that led to a coarse xenotopic mosaic of calcite crystals. The average mineralogical composition is given by prevalent calcite and feldspars, followed by quartz and dolomite (sample 1), with rare or traces of phyllosilicates and iron oxides (tab. 3). The presence of quartz and dolomite shows that these rocks have been slightly silicified and dolomitized during a later recrystallization. Note that the silicification and dolomitization affect mainly the upper part of the lithostratigraphic section. Chemical analyses of these samples show quite low silica content (28-38 wt.\%): the fairly high carbonate content (24-32 wt.\%) and the high values of the LOI confirm the carbonate nature of those samples. Moreover, the upper part of the lithostratigraphic section is richer in silica and magnesium than the lower part, confirming the silicification and dolomitization of the upper part.

Petrofacies 2: Claystone/siltstone (samples 3A, 3B, and 3C) show a very fine clayey matrix that contains the former rare small crystals of quartz and the latter abundant small grains of quartz (average dimension $0.05 \mathrm{~mm}$ ). In both rocks, the coarser fraction is composed of fine needles of muscovite and chlorite well oriented to the surface and few grains of opaque minerals (iron oxides and pyrite). The mineralogical composition is made up of a small amount of quartz and carbonates, whereas chlorite, illite, and mica minerals are present in high content. Feldspars are more abundant in siltstones while iron oxides are present in both rocks in traces. The chemical composition of these samples is silico-aluminous $\left(\mathrm{SiO}_{2}=58-60\right.$ wt. $\%$ and $\mathrm{Al}_{2} \mathrm{O}_{3}=17-18$ wt.\%), comparable with that of clay. The relatively high content of magnesium $(\mathrm{MgO}=3,2-3,7$ wt. $\%)$ and potassium $\left(\mathrm{K}_{2} \mathrm{O}=5,3-5,6\right.$ wt.\%) and a LOI of about 4-5 wt.\% are related to the richness of these rocks in mica minerals, including chlorite.

Petrofacies 3: Arkosic sandstone (samples 2, 5, and 9B) are composed mainly of angular grains of quartz and by minor amount of plagioclase, often twinned. In sample 5, mica flakes (often chloritized) have been detected. Instead, these minerals are absent in sample 9B, which contains significant amounts of opaque minerals (iron oxides and sulphides). In both samples, carbonatic cement is also present. The dimension of grains of these arenites is too fine to be point-counted, although due to their compositions they can be classified as arkose (or subarkose), according to GAzzI et alii (1973). The mineralogical composition shows a high content in quartz and feldspars; carbonates, phillosilicates, and iron oxides appear in low amounts and/or traces. The results from chemical analyses confirm the quartzose nature showing a high content of $\mathrm{SiO}_{2}$ (68-73 wt.\%). The average content of aluminium and alkali $\left(\mathrm{Al}_{2} \mathrm{O}_{3}=12-13\right.$ wt.\%; $\mathrm{Na}_{2} \mathrm{O}+\mathrm{K}_{2} \mathrm{O}=7,6-5,5$ wt. $\%$ ) is related to the abundant presence of feldspars, as indicated by X-ray diffraction.

Petrofacies 4: Schist (sample 6) shows a matrix rich in small quartz grains and some plagioclase. The coarse fraction is characterized mainly by chlorite, often twisted 

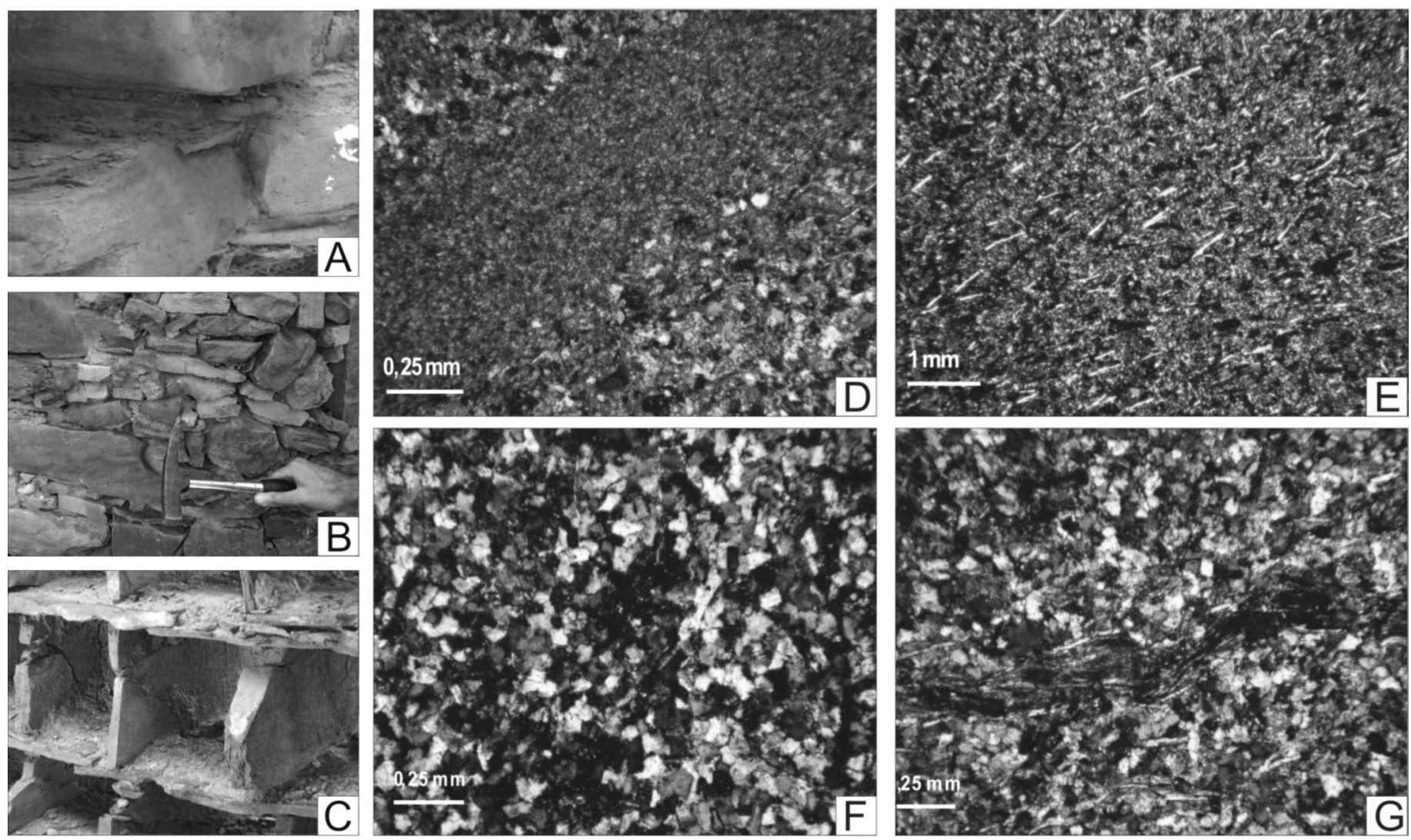

Fig. 4 - Pictures of some representative samples collected in the Amtoudi Agadir and micrographs of the main petrofacies recognized: A) sample P-01: arkosic sandstone, petrofacies $3 ; B$ ) sample P-05, wackstone/grainstone, petrofacies $1 ; C$ ) sample P-08: claystone/siltstone, petrofacies 2; $D$ ) sample P-04, wackstone/grainstone, microfacies 1; E) sample P-02, claystone/siltstone, microfacies 2; $F$ ) sample P-01, arkosic sandstone, microfacies 3; G) sample P-10, schist, microfacies 4.

and oriented parallel to the schistosity planes. Some opaque minerals are visible. Mineralogical composition is comparable to that of the arenites, with similar quartz and feldspar contents, and a higher content of illite/mica and chlorite (tab. 3). Carbonates were not found. Even the chemical analysis is comparable to that of arenites, showing similar content of silica $\left(\mathrm{SiO}_{2}=70 \mathrm{wt} . \%\right)$ and a slightly higher percentage of aluminium $\left(\mathrm{Al}_{2} \mathrm{O}_{3}=14\right.$ wt.\%) and iron $\left(\mathrm{Fe}_{2} \mathrm{O}_{3} \mathrm{~T}=4\right.$ wt.\%).

A detailed examination of the stones used in the construction of walls and towers of Amtoudi Agadir revealed that these are of varying petrographic nature and were used almost in the raw state (fig. 1). Note that more than $90 \%$ of stones come from the same site. The dimensions of the stones do not exceed those of rubble (rock fragment which can be lifted by one person). Petrographically, we find among the stones in the constructive elements of the agadir the four petrofacies previously defined and described (fig. 4A, 4B, 4C; tab. 1): wackestone/grainstone (P-04 and $\mathrm{P}-05$; Petrofacies 1$)$; claystonel siltstone (samples P-02, P-06, P-07, and P-08; Petrofacies 2); arkosic sandstone (samples P-01 and P-03; Petrofacies 3); schist (samples P-09 and P-10; Petrofacies 4). Petrofacies 3 (arkosic sandstone) is preferred, due to its hardness and fracture type in slabs or rectangular prisms, for stone joists and beams of the ceiling structures, stone lintels and isolated stone pillars. The other petrofacies are used interchangeably in all types of walls. Microscopic examination of the stones used in building walls shows same structure and mineralogy as the rock samples coming from the field. The micrographs of the Amtoudi building stones are displayed in fig. 4D to 4G.

Regarding the mineralogical composition (tab. 3), the limestone samples (P-04, P-05) consist mainly of calcite, plagioclase, and K-feldspar; minor amount of quartz and phillosilicates (above all illite/mica) and traces of pyroxenes are also present. The claystone/siltstone samples (P-02, P-06, P-07, and P-08) are composed by abundant feldspars and phillosilicates, a low abundance of quartz and calcite, and traces of dolomite, pyroxenes, and hematite. The arkosic sandstone samples (P-01 and $\mathrm{P}-03)$ are composed of abundant quartz, plagioclase, chlorite, and illite, with minor amount of K-feldspar and traces of pyroxene, dolomite, and calcite.

With respect to the mortars, original design and successive repairs of Amtoudi Agadir used traditional materials, as well as, local and ancestral constructive techniques consisting of harnessing the zone resources. Since this region is an economically very depressed one, materials of industrial origin are not used for the constructions or repairing. Therefore, in the Amtoudi area, the mortar is performed with two solid components and an excessive proportion of water. The solid components are: (1) a natural material coming from the richest clay levels of the intervals $\mathrm{B}$ and $\mathrm{D}$ of the succession (fig. 3D) of the proper bedrock (this material is not an industrial or artificial aggregate and any treatment is performed on it); (2) the binder. 
TABLE 4

Grain size analyses and Atterberg limits tests results performed on mortar samples from Amtoudi Agadir.

\begin{tabular}{|c|c|c|}
\hline \multicolumn{3}{|c|}{$\begin{array}{l}\text { Sieve gradation test according to UNE 103.101/95 norm } \\
\text { Sediment grain size test according to UNE 103.102/95 norm }\end{array}$} \\
\hline \multirow{2}{*}{ Sieve sizing $(\mathrm{mm})$} & \multicolumn{2}{|c|}{ Passing $(\%)$} \\
\hline & M-10 & M-12 \\
\hline 25 & 100 & 100 \\
\hline 20 & 100 & 97.0 \\
\hline 10 & 100 & 81.1 \\
\hline 5 & 100 & 70.2 \\
\hline 2 & 100 & 64.2 \\
\hline 1,25 & 99,9 & 61.0 \\
\hline 0,40 & 99,7 & 55.3 \\
\hline 0,16 & 99,4 & 50.2 \\
\hline 0,080 & 96,5 & 43.6 \\
\hline 0,063 & 79,7 & 42.2 \\
\hline 0,034 & 67,0 & 30.0 \\
\hline 0,013 & 44,7 & 21.6 \\
\hline 0,007 & 31,9 & 13.1 \\
\hline 0,004 & 15,9 & 7.5 \\
\hline 0,002 & 6,4 & 1.9 \\
\hline
\end{tabular}

Atterberg limits test according to UNE 103.103/94 and UNE 103.104/93 norms

\begin{tabular}{c|c|c}
\hline Parameter & M-10 & M-12 \\
\hline Liquid limit & 41,4 & 27.1 \\
\hline Plastic limit & 26,0 & 19.9 \\
\hline Plasticity index & 15,4 & 7.2 \\
\hline
\end{tabular}

TABLE 5

Composition and classification of mortar samples from Amtoudi Agadir.

Composition and classification of mortar samples

\begin{tabular}{c|c|c}
\hline Parameter & M-10 & M-12 \\
\hline Gravel content & 0 & 35.8 \\
\hline Sand content & 20.3 & 4.5 \\
\hline Silt content & 73.3 & 57.8 \\
\hline Clay content & 6.4 & 1.9 \\
\hline $\begin{array}{c}\text { Casagrande } \\
\text { classification }\end{array}$ & ML & GM \\
\hline $\begin{array}{c}\text { Highway Research } \\
\text { Board classification }\end{array}$ & A7-6 & A4 \\
\hline Group index & 10 & 2 \\
\hline Description & $\begin{array}{c}\text { Sandy silt with } \\
\text { medium plasticity }\end{array}$ & $\begin{array}{c}\text { Poorly graded mixture } \\
\text { of gravel and silt }\end{array}$ \\
\hline
\end{tabular}

The clayed raw material was sampled (M-10 and M-12) and tested (tab. 4), resulting (tab. 5) also composed of a mixture of clays (up to 6.5\%) and a certain proportion of gravels (up to $36 \%$ ), sands (up to $20 \%$ ), and silts (up to $73 \%$ ).
The binder is (a very impure) calcium oxide $(\mathrm{CaO})$, commonly known as quicklime powder (or burnt lime) derived from the cooking of limestones also from the proper bedrocks by using rudimentary ovens existing in the Amtoudi area. The quicklime powder shows a high proportion of impurities together with ashes from the cooking. These impurities are calcareous material that did not burn well in the calcinating process and clayey remains or other minerals that the original limestones contained because these were not $100 \%$ carbonate. All these impurities make the quicklime of bad quality decreasing its properties as binder. The ratio binder/natural clayish material, used traditionally, is about 1/9 giving a bad quality mortar that slowly hardens in contact with air by the atmospheric carbon dioxide action.

The results lead us to classify sample M10 as sandy silt with medium plasticity and sample M12 as a poorly graded mixture of gravel and silt (tab. 5). The mean moisture and specific weight for the mortar were calculated through the Grundbau-Taschenbuch parameter table. Results: $20 \%$ moisture, $15.0 \mathrm{kN} / \mathrm{m}^{3}$ dry specific, and $18.0 \mathrm{kN} / \mathrm{m}^{3}$ apparent specific weights were used to calculate wall stability in the Discussion section.

An inventory of wooden elements and associated problems was compiled. In the agadir the wood is used for ceiling structures, lintels, and carpentry elements. The ceiling structures were made of large trunks of palm or argan trees held up by the load-bearing elements and supporting the ceiling (fig. 1G). The average dimensions of the beams were about $0.3-\mathrm{m}$ spacing, 2.35-m length, and $55-\mathrm{cm}^{2}$ cross section. Over the beams, palm leaves sometimes appear interlaced (fig. 1G), supporting the filling of the ceiling structure consisting in a thin layer of gravel. Lintels were made from the solid portion of argan trees (square in section and having a width reaching $20 \mathrm{~cm}$ ) and framed doors or windows to support the weight of the wall above the opening (fig. 1I). Carpentry elements included mainly olive-wood doors, windows, and window shutters (fig. 1H, 1I).

\section{CONSTRUCTION TECHNIQUES AND ARCHITECTONIC ELE- MENTS}

The agadir was built directly on a rocky piton following the irregularities of the bedrock surface to better anchor the building to the substratum (fig. 1C, 1D, 1J). Original design and successive repairs of Amtoudi Agadir used traditional materials: local stones, scarce clays, lime basic/clay-based mortars, and argan and palm wood, as well as local constructive techniques consisting of harnessing environmental resources. The sub-horizontal stratification plan of the Amtoudi lithological formation has certainly served to obtain more regular stones, which are quite easy to use directly in construction. The walls were usually built with horizontal interlocking of stones with small amounts of rough mortar (fig. 1F, 1K). In some places the stones are arranged in a mixed way: horizontal and oblique (fig. 1L). Other parts of the walls are constructed by adopting a horizontal alignment style of large and flat stones with intercalation of small stones and aggregates by using a thin layer of mortar (fig. 1M).

The architectonic elements of the Amtoudi Agadir were classified according to the function as load-bearing structural elements and supported structural elements. The first ones consisted of gravity walls (fig. $1 \mathrm{H}$ to $1 \mathrm{O}$ ) 

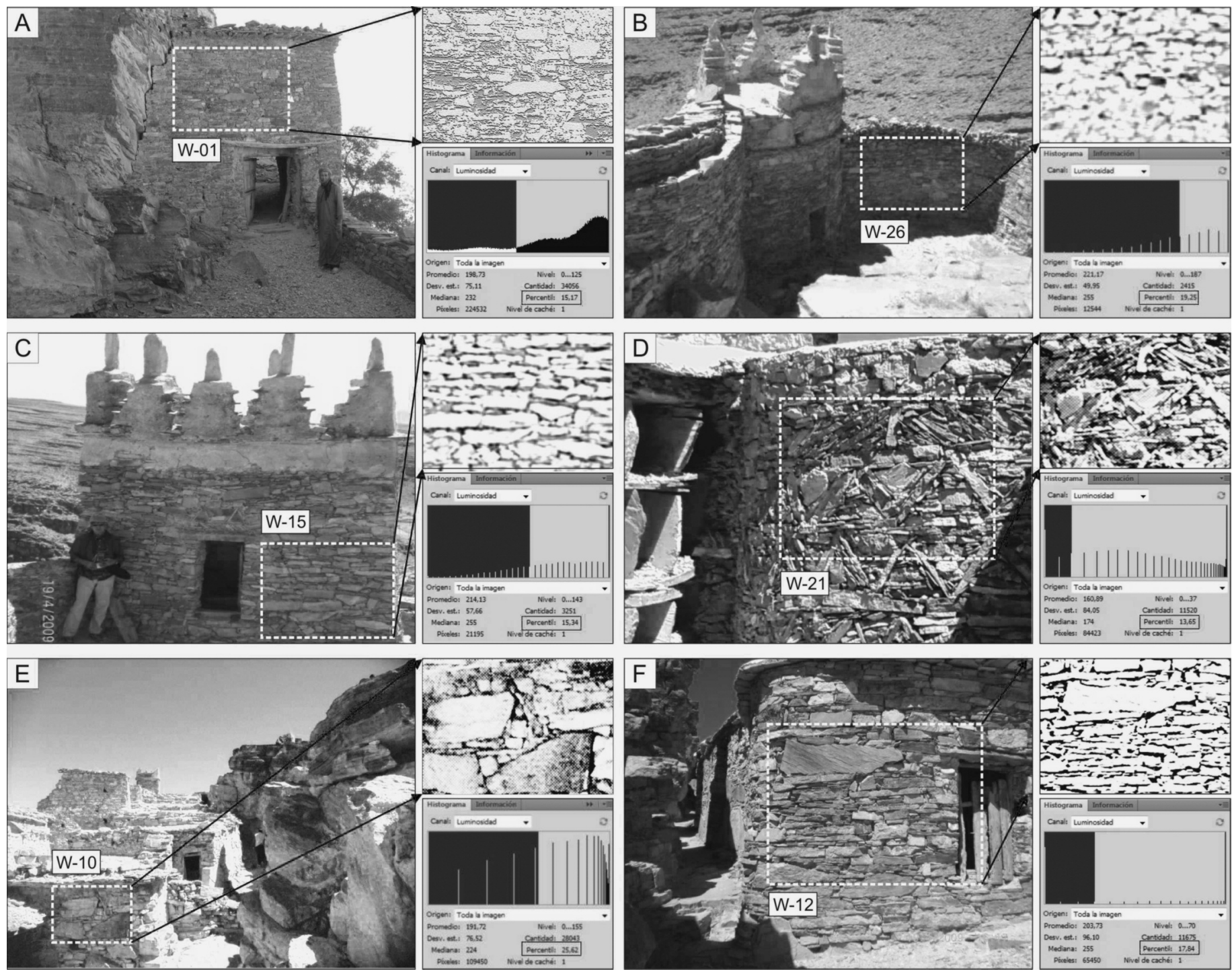

Fig. 5 - Images processing from digital photos to calculate the porosity of the walls of the Amtoudi Agadir.

of 1 to 2-m high appearing mainly on the exterior sides of the Agadir. They were made by accumulation of stacked flat rock fragments with lack interlocking joints in the masonry. They have small amounts of mortar and, in some cases, resemble a small, rough ashlar. The buttresses (fig. $1 \mathrm{~N}$ ) reinforcing the exterior sides of the walls or towers are also composed of stacked flat rock fragments in a same way as the gravity walls. Load-bearing walls (0.30 to $0.50 \mathrm{~m}$ thick and less than $0.3 \mathrm{~m}$ high walls appearing as partition rooms and to support the ceilings, were built by stacking flat rock fragments, but in this case joined by a clay and lime mortar) and isolated pillars support part of the ceiling load, allowing circulation within the enclosed space, consisting of piers and columns made of a monolithic prismatic stone (fig. $1 \mathrm{H}$ ) with centimetric diameters or also prismatic centimetric to decimetric masonry walls (fig. 10).

The supported structural elements are ceiling structures (fig. 1E, 1G, 1O) made of beams resting on the loadbearing walls, flat stones over the beams or interlaced palm leaves (supporting the gravelly fill topped by a thin layer of mortar made of clay and lime), and lintels (fig. 1H, 1I) appearing over the openings in the walls for windows and doors. These consist of sturdier beams $20 \mathrm{~cm}$ in width made of solid argan timber or stone, embedded in the wall and supporting the weight of the wall above the opening.

\section{Load-bearing structural elements (stone walls, buttresses, and pillars)}

All these elements in reality are part of masonry walls (varying the dimensions), and the study has been performed for these into two steps. First, the calculation of the "porosity" following the procedures of THORNBUSH \& VILES (2008), ThorNBush $(2013,2014)$ and references therein, after the image processing of digital photographs consisting of determining the "porosity" (ratio between void volume between stones and the total volume). Some of the case-studies treated here are presented in fig. 5. The "porosity" calculated was transformed into an estimated apparent specific weight of the wall, buttresses, and pillars since the stones and the mortar of the wall were tested in laboratory and the specific weights of these are known (tab. 6). 


\section{TABLE 6}

Calculation of the specific weight of the walls of the Amtoudi Agadir, according to the porosity data collected.

\begin{tabular}{|c|c|c|c|c|}
\hline \multicolumn{2}{|c|}{$\begin{array}{l}\text { Mean apparent specific weight of mortar: } \\
\text { Mean specific weight of the stone: }\end{array}$} & $\begin{array}{l}18,00 \\
26,51\end{array}$ & $\begin{array}{l}\mathrm{kN} / \mathrm{m}^{3} \\
\mathrm{kN} / \mathrm{m}^{3}\end{array}$ & \multirow[b]{2}{*}{$\begin{array}{c}\text { Aparent } \\
\text { specific weight } \\
\text { with mortar } \\
\left(\mathrm{kN} / \mathrm{m}^{3}\right)\end{array}$} \\
\hline Sample & $\begin{array}{l}\text { Location in the } \\
\text { Amtoudi Agadir }\end{array}$ & Porosity & $\begin{array}{c}\text { Aparent dry } \\
\text { specific weight } \\
\left(k N / m^{3}\right)\end{array}$ & \\
\hline W01 & Exterior wall (entrance $\mathrm{N}$ agadir) & 0.1517 & 22.49 & 25.22 \\
\hline W02 & Interior wall (W agadir) & 0.2380 & 20.20 & 24.48 \\
\hline W03 & Interior wall (E agadir) & 0.2252 & 20.54 & 24.59 \\
\hline W04 & Interior wall (SW tower) & 0.1964 & 21.30 & 24.84 \\
\hline W05 & Interior wall (entrance $\mathrm{S}$ agadir) & 0.1793 & 21.76 & 24.98 \\
\hline W06 & Interior wall (entrance $\mathrm{S}$ agadir) & 0.2483 & 19.93 & 24.40 \\
\hline W07 & Interior wall (entrance $\mathrm{S}$ agadir) & 0.3077 & 18.35 & 23.89 \\
\hline W08 & $\begin{array}{c}\text { Interior wall } \\
\text { (near entrance } \mathrm{W} \text { agadir) }\end{array}$ & 0.2686 & 19.39 & 24.22 \\
\hline W09 & Interior wall (S agadir) & 0.2558 & 19.73 & 24.33 \\
\hline W10 & $\begin{array}{c}\text { Interior wall } \\
\text { (near entrance } \mathrm{W} \text { agadir) }\end{array}$ & 0.2562 & 19.72 & 24.33 \\
\hline W11 & $\begin{array}{c}\text { Interior wall } \\
\text { (museum house, } \mathrm{N} \text { agadir) }\end{array}$ & 0.2023 & 21.15 & 24.79 \\
\hline W12 & $\begin{array}{l}\text { Interior wal } \\
\text { (S house to the } \mathrm{N} \text { of hives) }\end{array}$ & 0.1784 & 21.78 & 24.99 \\
\hline W13 & $\begin{array}{l}\text { Interior wall (entrance } \\
\text { museum house, N agadir) }\end{array}$ & 0.2155 & 20.80 & 24.68 \\
\hline W14 & Interior wall (house, W agadir) & 0.2156 & 20.79 & 24.68 \\
\hline W15 & Exterior wall (N wall SE tower) & 0.1534 & 22.44 & 25.20 \\
\hline W16 & Exterior wall (W wall SE tower) & 0.1631 & 22.19 & 25.12 \\
\hline W17 & Exterior wall (S wall NW tower) & 0.2177 & 20.74 & 24.66 \\
\hline W18 & Interior wall (W agadir) & 0.1825 & 21.67 & 24.96 \\
\hline W19 & Exterior wall (E wall SW tower) & 0.2014 & 21.17 & 24.80 \\
\hline W20 & Interior wall ( $\mathrm{E}$ of hives) & 0.2793 & 19.11 & 24.13 \\
\hline W21 & $\begin{array}{l}\text { Interior wall ( } \mathrm{E} \text { of beehives) } \\
\text { triangular rig }\end{array}$ & 0.1365 & 22.89 & 25.35 \\
\hline W22 & $\begin{array}{l}\text { Exterior wall (near entrance W } \\
\text { agadir) repaired }\end{array}$ & 0.2740 & 19.25 & 24.18 \\
\hline W23 & $\begin{array}{c}\text { Exterior wall (near entrance W } \\
\text { agadir) repaired }\end{array}$ & 0.2746 & 19.23 & 24.17 \\
\hline W24 & $\begin{array}{c}\text { Exterior wall } \\
\text { (above the entrance NW) }\end{array}$ & 0.1981 & 21.26 & 24.82 \\
\hline W25 & Exterior wall (near the SE tower) & 0.2345 & 20.29 & 24.51 \\
\hline W26 & Exterior wall (near the SW tower) & 0.1925 & 21.41 & 24.87 \\
\hline W27 & Exterior wall (near entrance W) & 0.2991 & 18.58 & 23.96 \\
\hline
\end{tabular}

The second step, once the specific weights are known, was to calculate the safety of the masonry walls for the worst-case failure (flexural buckling). Therefore, several calculations with the variable of the mortar strength and the height and the thickness of the masonry walls were performed in the worst cases. The resulting range of safety factor (bearing in mind that the minimum value required for safety factor is 1.0 and that the recommended value is 1.5 ) was as follows:

1. Two-height bridged masonry walls. Only a few of constructions with 2-height masonry walls have been found in the Amtoudi Agadir, these being towers and some houses (fig. 6A, 6B). The worst case (the SE tower) was studied and the heights measured are $1.9 \mathrm{~m}$, the lower one, and $2.6 \mathrm{~m}$, the upper one. The safety factor variation for flexural buckling was calculated according to the specific weight variation between 16 and $24 \mathrm{kN} / \mathrm{m}^{3}$, and the variation in strength of the mortar in three cases: $0.05,0.15$, and $0.45 \mathrm{kPa}$. Two thicknesses for the walls were considered, $0.20 \mathrm{~m}$ (fig. 6C) and $0.40 \mathrm{~m}$ (fig. 6D). The results indicate more stability for the $0.40 \mathrm{~m}$ thick wall. In the worst case, the wall $0.20 \mathrm{~m}$ thick was stable when the strength of the mortar was greater than $0.15 \mathrm{kPa}$ for specific weight lower than $24 \mathrm{kN} / \mathrm{m} 3$ (fig. 6C).

2. One-height free-standing (unbridged) masonry walls. Usually the external wall of the agadir are 1-height free-standing masonry walls lower to $4 \mathrm{~m}$ height (fig. 7A, 7B, 7C). The safety-factor variation for flexural buckling was analysed according to the specific weight of the wall from 16 to $24 \mathrm{kN} / \mathrm{m}^{3}$, and the strength of the mortar (from 0.01 to $500 \mathrm{kPa}$ according to the walls). While 1-height free-standing walls of $2.6 \mathrm{~m}$ were analysed considering two thicknesses. i.e. $0.30 \mathrm{~m}$ and $0.40 \mathrm{~m}$, the thinner wall required more than $50 \mathrm{kPa}$ of mortar strength to ensure stability (fig. 7D), while the thicker one required values up to $0.01 \mathrm{kPa}$ of mortar strength (fig. 7E). When safetyfactor variation for flexural buckling was analysed according to the strength of the mortar $(0.05,0.5$ and $5 \mathrm{kPa})$ but with a specific weight of $20 \mathrm{kN} / \mathrm{m}^{3}$ (the mean of the estimations performed in the Amtoudi Agadir), a variable height of the walls from 2 to $4 \mathrm{~m}$ height, and two thicknesses: $0.30 \mathrm{~m}$ (fig. $7 \mathrm{~F}$ ) and $0.40 \mathrm{~m}$ (fig. 7G), the resulting curves showed a decreasing safety factor when the walls were higher. In these curves, as the strength of the mortar increased, the safety factor rose. In the walls $0.30 \mathrm{~m}$ thick, these were stable with heights lower than $2.2 \mathrm{~m}$ when the mortar strength was $0.05 \mathrm{kPa}$, lower than $2.4 \mathrm{~m}$ when the mortar strength was $0.5 \mathrm{kPa}$, and lower than $2.5 \mathrm{~m}$ when the mortar strength was $5 \mathrm{kPa}$. In the walls $0.40 \mathrm{~m}$ thick, these were stable with height lower than $2.9 \mathrm{~m}$ when the mortar strength was $0.05 \mathrm{kPa}$, lower than $3.4 \mathrm{~m}$ when the mortar strength was $0.5 \mathrm{kPa}$, and lower than $3.7 \mathrm{~m}$ when the mortar strength was $5 \mathrm{kPa}$.

\section{Supported structural elements (ceiling structures)}

These have been characterized by calculating the total nominal load, including its own weight and use load according to European norms. The calculations to assess the safety of the ceiling structures were performed in the two scenarios: when joists and beams are made of trunk and when made of stone (fig. 8) but it is normal to find mixed ceiling structures of stone and wooden joists and beams. The input data for calculations in ceiling structures appear in tab. 7. The possible combinations of joists, beams, and ceiling structures register a weight of between 4.22 and $6.20 \mathrm{kN} / \mathrm{m}^{2}$ (for a mean value of close to $5.0 \mathrm{kN} / \mathrm{m}^{2}$ ). Thus, as the use load considered according to European norms must be $2.0 \mathrm{kN} / \mathrm{m}^{2}$, a total mean nominal load over the ceiling structure (including its own weight and use load) can be estimated at close to $7.0 \mathrm{kN} / \mathrm{m}^{2}$. The safety check (fig. 8) consisted in determining by standard procedures used in the theory of structures (GERE, 2004) the worst scenario (the maximum traction and compression due to shear stress of the joists and beams). These tensions were compared with breaking 

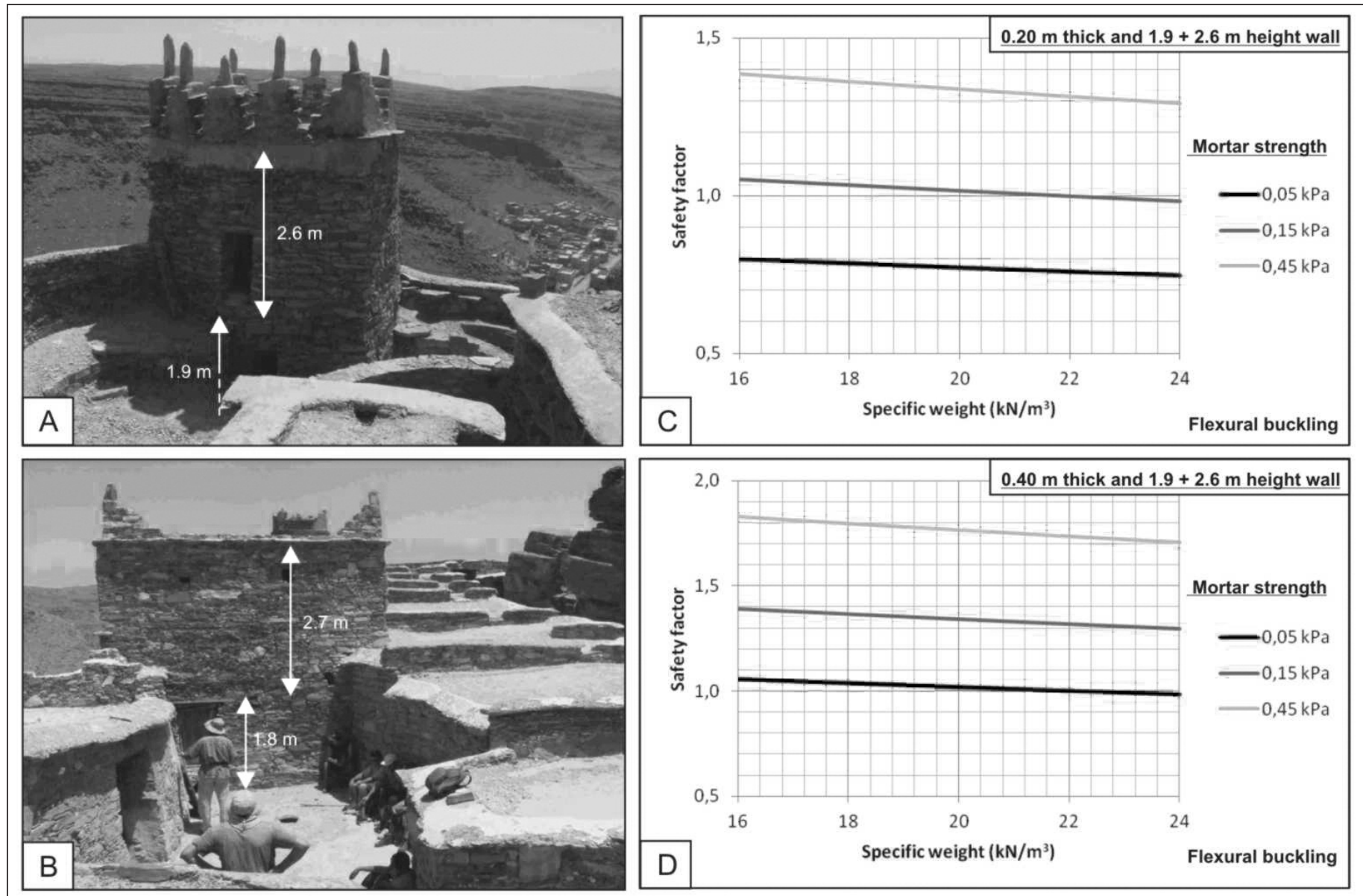

Fig. 6 - Two-height bridged masonry wall safety calculations for flexural buckling in Amtoudi Agadir.

stresses of the joists and beams under the corresponding efforts. As can be seen in fig. $8 \mathrm{C}$ and $8 \mathrm{D}$, the wooden joists and beams show a safety factor below 1.8, while the stone joists and beams show a safety factor higher than 2.5 , the minimum required being 1.5 . When the performance of material is reduced, the stone joists and beams show the higher safety factor, the reduction in performance of the material being far greater in wooden than stone. In the case of wooden joists, a reduction of about a $20 \%$ in the performance lowers the safety factor to below 1.5. On the other hand, a total overload of about a $125 \%$ (25\% over the nominal overload) implies safety factors of below 1.5. Nevertheless, in the case of stone joists, a safety factor of below 1.5 requires a reduction of about $67 \%$ in the performance of the stone and/or a total overload of about $300 \%$. Therefore, the worst case would be when joists are made of wood, and this case will be discussed in the following section.

\section{DISCUSSION: \\ STATE OF CONSERVATION AND MAINTENANCE}

\section{Rocks}

The Amtoudi area is located in an unpolluted, very hot and dry environment. Stone materials are exposed to continuous weathering caused by sudden hygrothermic changes, the wind action, and microorganism attacks. High temperature and daily thermal amplitude cause inner tensions in the mineral structures of the stone materials. The frequency and quickness of the thermal oscillations have more influence on deterioration processes than does the temperature amplitude (LAZZARINI \& LAURENZI TABASSO, 1986). Indeed, temperature ranges cause differential dilatations and internal tensions in the different mineralogical phases of stones. Diverging dilatations could take place between the minerals having different orientations, when they have random arrangement. With repeated temperature cycles, the internal stone stresses give rise to a gradual detachment of flacks and fragments from the surface layers. In heterogeneous stone materials, the different dilatation coefficient of minerals could also cause granular disintegrations and therefore loss of cohesion in stone materials themselves.

In this climatic environment the presence of moisture affects the state of conservation of the Amtoudi Agadir. In fact, water in all its phases has a leading role in every degradation mechanism, triggering acid attack, hydrolysis, and solubilization reactions, as well as favouring resilient biological processes. Moreover, water acts inside the stone to augment freeze and thaw cycles, and bringing about direct mechanical disruption.

As a result of these phenomena, the agadir shows a different conservation status. The following describes the main types of degradation and alteration found in the 

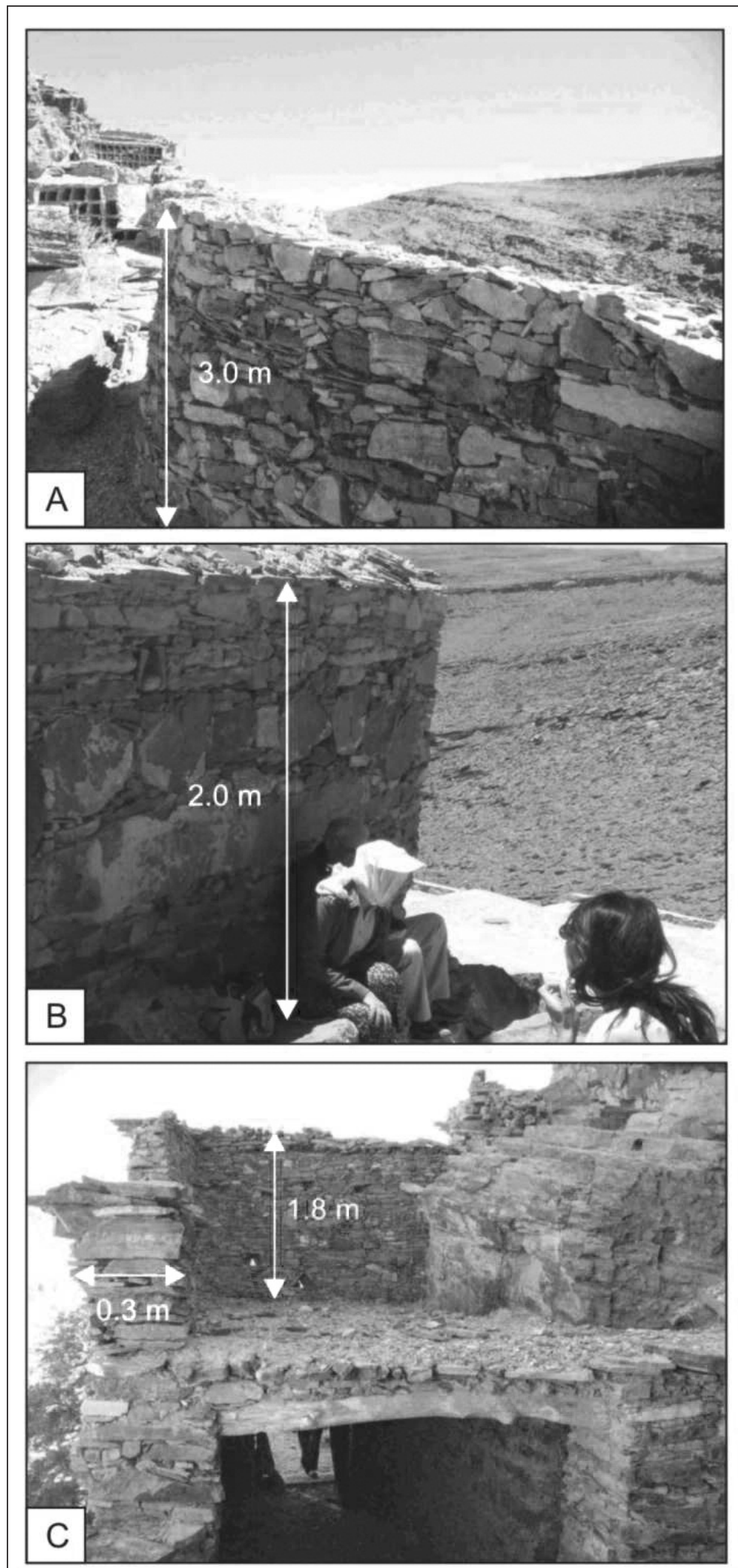
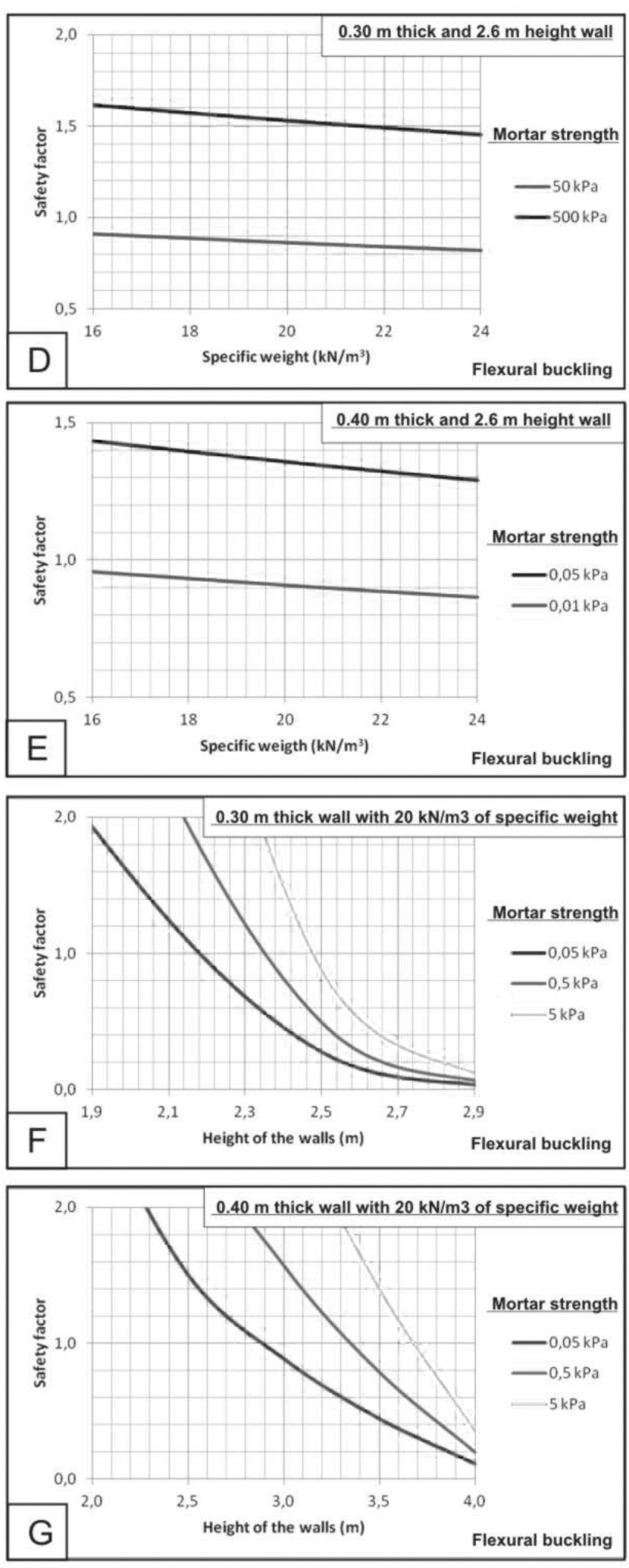

Fig. 7 - One-height masonry wall safety calculations for flexural buckling in Amtoudi Agadir.

rocks used in the architectonic complex, according to the standard European norms of conservation of Cultural Heritage, but also in the architectonic elements as in fig. 9: (i) Biological degradation (fig. 9A) is represented only by weedy vegetation and mud waps nests affecting some blocks independently of the petrofacies; (ii) Chromatic alteration and patina (fig. 9B) appear as variations of the original colour of all the stones independently of petrofacies; (iii) Failings, detachments, and gaps take the form of small losses of morphological elements and the 

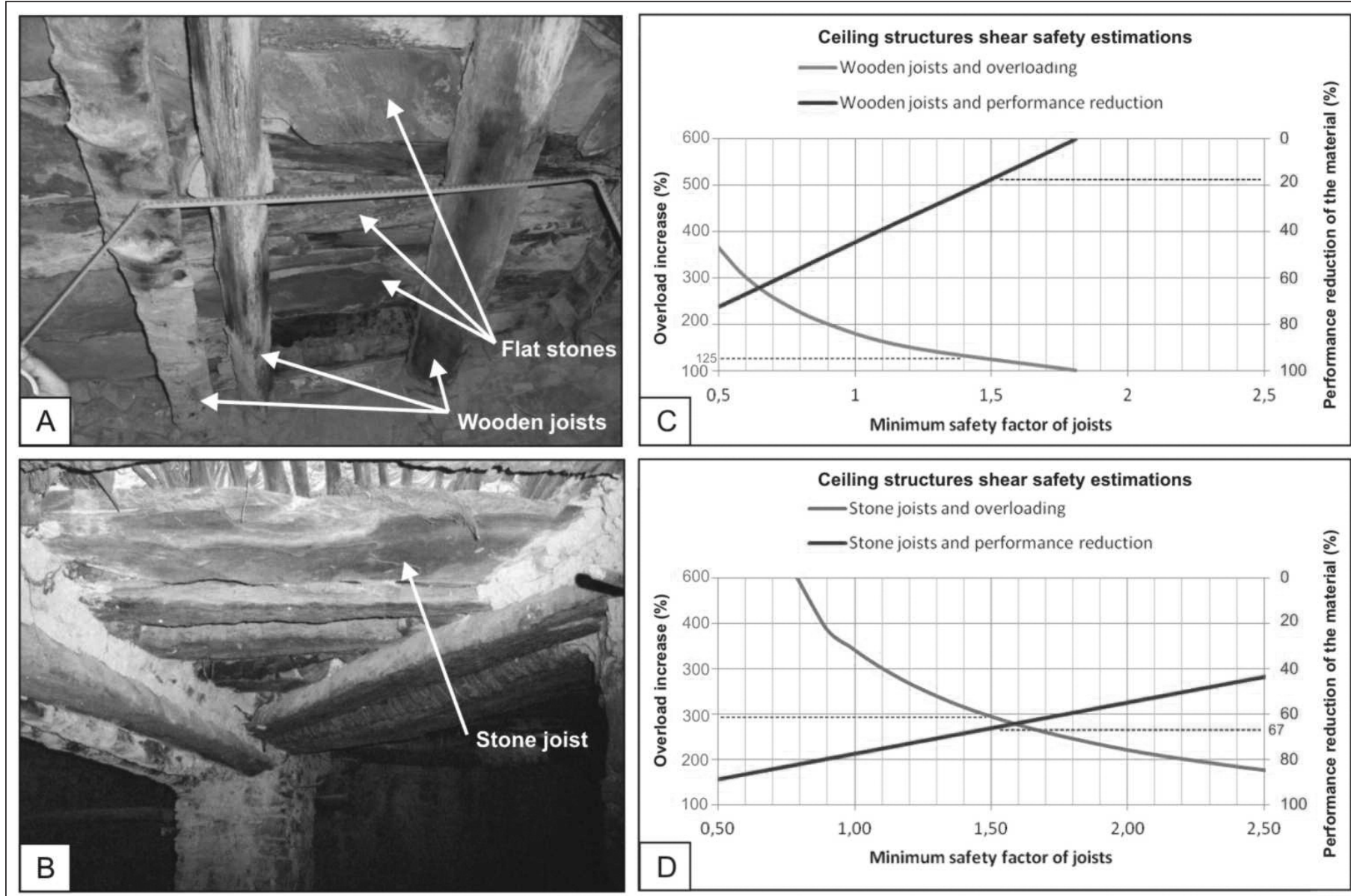

Fig. 8 - Ceiling structures shear safety estimations for overload increase and performance reduction of material of the Amtoudi Agadir: $A$ ) ceiling structure with wooden joists; $B$ ) safety factor graphics for wooden joists; $C$ ) ceiling structure with stone joist and beams; $D$ ) safety factor graphics for stone joists.

presence of discontinuity between layers usually affecting Petrofacies 2, 3, and 4 (fig. 9A, 9D red arrows); (iv) Fracturation and jointing (fig. 9C) are reflected in the lack of consistency in some rocks, resulting in dislocation between the different parts, with the fractures being the most common case, affecting all the stones independently of petrofacies; ( $v$ ) Exfoliation and scaling (fig. 9D) provoke the detachment of sub-parallel beds and flakes of irregular shape corresponding to fractures, foliation, lamination, and veins of materials, and usually affecting Petrofacies 2 and 4; (vi) Erosion (fig. 9E) removes material usually affecting Petrofacies 1, 2, and 4 and that may sometimes exacerbate other problems.

At Amtoudi Agadir, the conservation and maintenance of the stones should take into account the constituent materials, their physical and chemical compatibility with the restoration products, and environment conditions (AA.VV., 1986; ANDREWS, 1991). Where the material is affected by biological attack, a biocide treatment is firstly required. The treatment must be undertaken with broad-spectrum quaternary ammonium salts and with mechanical finishing where residues of the biological attack remain. The use of hydrogen peroxide should be avoided because it can mineralize impurities (iron oxides), staining the surface of the stone. In presence of particularly severe surface degradation, the cleaning of the stone elements should be preceded by a pre-consolidation of the surface meant to avoid further loss of material. Cleaning operations should be conducted in a controlled, gradual, and selective manner, using deionised water spray at low pressure, from the top downwards, varying the duration of the treatment according to the tenacity of the dirt and possibly repeating the operation several times. If necessary, the cleaning action of the water should be aided by a simultaneous brushing with sorghum brush or nylon. Different techniques other than those described above (e.g. mechanical cleaning with precision blasting with aluminium oxide, vibroengraver, cleaning by means of specific chemical agents or with the use of special absorbent clays) should be appropriately evaluated according to each situation, but the use of distilled water in jets should be avoided.

The restoration of fractures and gaps (where necessary) will require pure lime, slaked lime and aggregates in different colours according to the lithotype to be filled. Since in the original construction of the agadir plaster is not present, the use of plaster, cement mortar, epoxy resin, and acrylic resin is not recommended so as to avoid altering the appearance of the agadir.

The protective treatments on the outer surface of the stone material should be undertaken only in cases of excessive water absorption, these being harmful for good conservation. This protective treatment should be performed with products capable of inhibiting the hydrophilicity 
TABLE 7

Characteristics of the ceiling structures and joists from Amtoudi Agadir.

\begin{tabular}{c|c|c}
\hline GENERAL CHARACTERISTICS OF THE CEILING STRUCTURES \\
\hline Element & \multicolumn{2}{|c}{ Characteristic } \\
\hline Palm leaves board sheathing & Own weight & $0.01 \mathrm{kN} / \mathrm{m}^{2}$ \\
\hline Shank board sheathing & Own weight & $0.02 \mathrm{kN} / \mathrm{m}^{2}$ \\
\hline Flat stone board sheathing & Own weight & $0.80 \mathrm{kN} / \mathrm{m}^{2}$ \\
\hline Crushed gravel & Own weight & $3.15 \mathrm{kN} / \mathrm{m}^{2}$ \\
\hline Clay and lime topping & Own weight & $0.95 \mathrm{kN} / \mathrm{m}^{2}$ \\
\hline Wooden joists & Own weight & $0.10 \mathrm{kN} / \mathrm{m}^{2}$ \\
\hline Stone joists and beams & Own weight & $0.95 \mathrm{kN} / \mathrm{m}^{2}$ \\
\hline Mean spacing of joists and beams & Length & $0.33 \mathrm{~m}$ \\
\hline Mean length of joists and beams & Length & $2.35 \mathrm{~m}$ \\
\hline Mean tail in wall of joists and beams & Length & $0.23 \mathrm{~m}$ \\
\hline Use load according European norms & Total weight & $2.00 \mathrm{kN} / \mathrm{m}^{2}$ \\
\hline
\end{tabular}

\section{JOISTS AND BEAMS CHARACTERISTICS}

\begin{tabular}{c|c|c}
\hline Characteristic & Wooden ones & Stone ones \\
\hline Mean shape of the cross section & Triangular & Rectangular \\
\hline Mean cross section $\left(\mathrm{cm}^{2}\right)$ & 57.7 & 120.0 \\
\hline Mean height $(\mathrm{cm})$ & 10.0 & 8.0 \\
\hline Mean inertia $\left(\mathrm{cm}^{4}\right)$ & 236.0 & 640.0 \\
\hline Characteristic compressive strength $(\mathrm{MPa})$ & 23,7 & 132,3 \\
\hline Tensile stress at break $(\mathrm{MPa})$ & 43.3 & 25.0 \\
\hline Shear breaking stress $(\mathrm{MPa})$ & 0.85 & 13.2 \\
\hline Elasticity modulus $(\mathrm{MPa})$ & 2900 & 60300 \\
\hline
\end{tabular}

of the capillary walls and the external surface of the stone without reacting with the components of the stone material, leaving the water permeability from the inside, and without inducing surface alterations or colour changes.

\section{MORTARS AND WOODEN ELEMENTS}

The mortar used for the construction of the agadir was made with two solid components and an excessive proportion of water. The solid components are: a natural material coming from the richest clay levels (but with certain content in gravels, sands, and silts) of the proper bedrock (this material is not an industrial or artificial aggregate and any treatment is performed on it); and a very impure calcium oxide $(\mathrm{CaO})$, commonly known as quicklime powder as binder. The ratio binder/clayed raw, used traditionally, is about $1 / 9$ giving a bad quality mortar that slowly hardens in contact with air. These materials have been used both in masonry walls and ceiling structures as binders among stones. The main problem of such construction elements is the loss of mortar quality and, mainly, the washing out and erosion (due to rain and wind) of the mortar of the masonry walls, this process affecting the walls progressively from the outside in. When mortar is washed out, the walls seriously decrease in terms of the safety factor (see: fig. 6 and 7). The problems undergone by mortars affect mainly the stability of masonry walls, as will be discussed below.
The alteration of wooden elements consists of the loss of quality due to fatigue, rot or insects attacks (e.g. termites). In the case of the agadir these problems seriously affect the lintels, joists, and beams with the subsequent falling of ceiling structures. In fact, when joists and beams are deteriorated they flex progressively until shearing (tab. 8). This affects mainly the stability of ceiling structures, as discussed below.

\section{CONSTRUCTION TECHNIQUES AND ARCHITECTONIC ELE- MENTS}

Most of the techniques used for the construction of the agadir were ancestrals, and the structural elements show evidence of fatigue resulting in failures of construction or maintenance (tab. 8). The main problems of loadbearing structural elements (walls, buttresses, and pillars) and supported structural elements (ceiling structures) are discussed below.

\section{Load-bearing structural elements (stone walls, buttresses, and pillars)}

All these elements are constructed in the Amtoudi Agadir as masonry stone walls. The stability of stone walls depends directly on the geometric characteristic and their specific weigh while in the case of "gravity walls", it is directly proportional to the specific weight (weight per unit length) considering stones and also the mortar, according to the mechanical principles. On the contrary, for the structural walls involved in the edifications as rooms and towers, the stability was influenced not only by the geometric constraints and by the whole structure, but also by the specific weight (since the stability increases with the specific weight). Thus, this discussion will be focused on the gravity masonry walls.

Since the specific weight of the stones used is very high, as explained in the Results section, the worst cases belong to thin, high masonry walls affected by loss of quality, and mainly, washing out and erosion of the mortar. As explained in figs. 6 and 7, the safety factor of the masonry walls diminished when the thickness decreased and wall height increased, as well as when the quality or the proportion of mortar decreased, the worst case being the flexural buckling (fig. 9F; fig. 10A, 10B). Therefore, as the main problems derive from excessively thin construction of the walls without the interlocking of the rocks and from the low proportion of mortar joining the rocks, it is recommended to avoid: (1) the construction of 2-height bridged masonry walls (with a maximum height of $4.5 \mathrm{~m}=1.9 \mathrm{~m}+2.6 \mathrm{~m}$ ) with a thickness of the wall lower to $0.4 \mathrm{~m}$; (2) construction of 1-height free-standing masonry walls (the worst case shows $2.6 \mathrm{~m}$ height) with a wall thickness of less than $0.3 \mathrm{~m}$. In such cases, when thickness is lower than recommended, if the mortar is removed or its quality lowers, wall safety is not guaranteed.

\section{Supported structural elements (ceiling structures)}

A safety factor has been established for ceiling structures using the nominal load calculated in the Results section $\left(7.0 \mathrm{KN} / \mathrm{m}^{2}\right)$ according to the usual safety criteria of values below 1.5 imply risk of failure. For the calculation, two conditions were considered (fig. 8): (1) the load over the ceiling structure was progressively increased; (2) the performance of the material of the joists and beams 

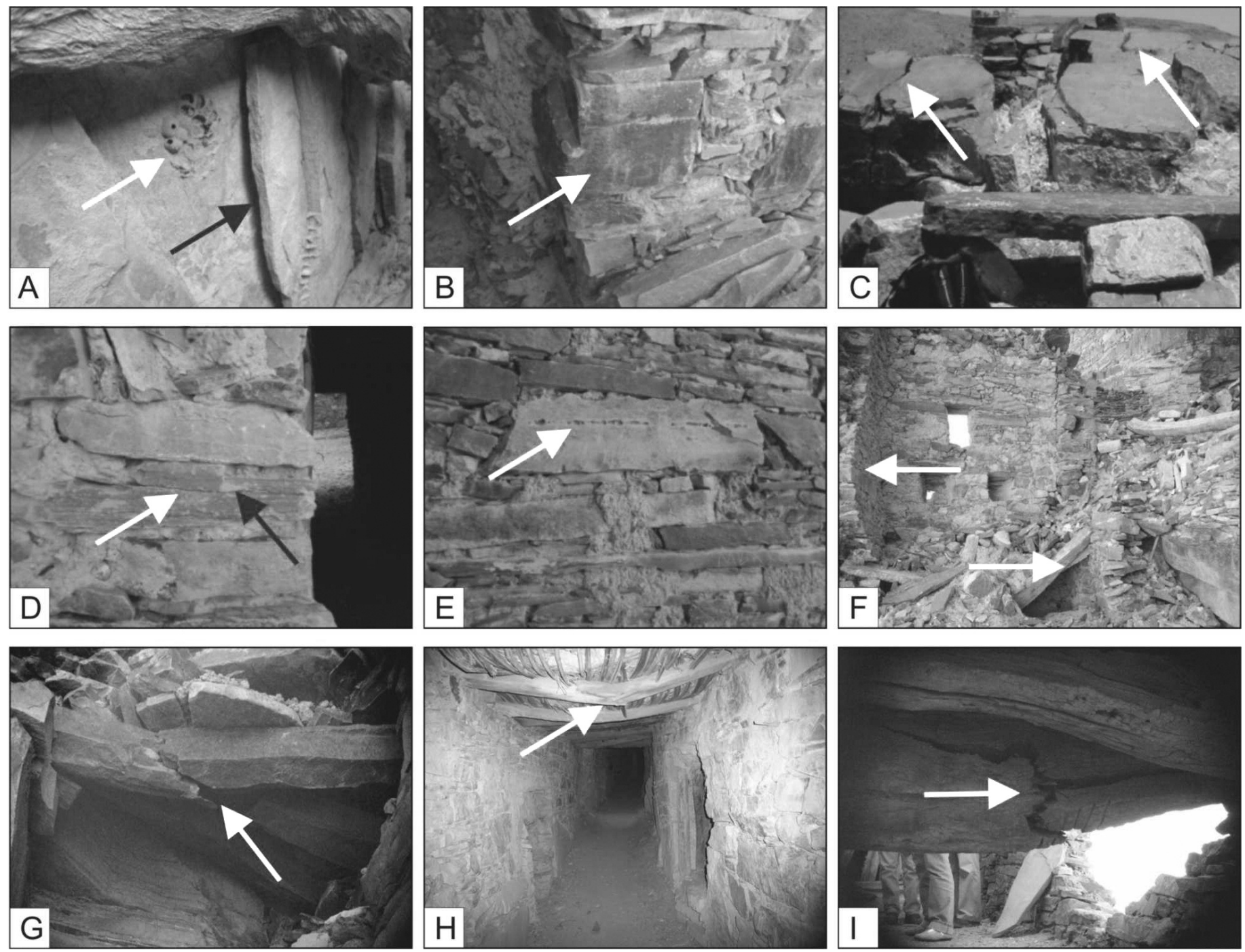

Fig. 9 - Main typologies of degradation, alteration and failures concerning the used rocks and the constructive elements of the Amtoudi Agadir: A) biological degradation (upper arrow) and detachment (lower arrow); $B$ ) chromatic alteration and patina; $C$ ) fracture and jointing; $D$ ) exfoliation (left arrow) and failing (right arrow); $E$ ) erosion; $F$ ) unstable walls affected by flexural buckling; $G$ ) sheared stone joist; $H$ ) sheared wooden joist; $I$ ) incipient shearing affecting wooden joist.

was reduced due to rot, insect attack, or material fatigue (=reducing the flexural elastic modulus). The increase in overload and the decrease of performance of the joists and beams reduced the safety factor of the ceiling structure, the worst case being when they are made of wood (fig. 8). In this latest case, the combination of the two problems (an overload and a decreasing in the performance of the wood) constitutes a serious danger. The unique advantage of the wood is the manner of damage, which is progressive and failure can be predicted. On the contrary, stone breaks suddenly and less predictably (fig. 9G).

Studies of the three possible failures (traction, compression and shear) for overload over the ceiling structure and for reduction of the performance of the wooden joists and beams (the worst case) evidenced that the worst failure is the shearing (fig. 9G to 9I; fig. 10C, 10D) rendering lower safety-factor values in all cases. Therefore, when the load is increased (fig. 10C), the response in the three cases (traction, compression or share) is quite similar (but shearing always being worst). With a total overload of about $125 \%$ (some $25 \%$ over the nominal overload), the
TABLE 8

Failures of the architectonic elements from Amtoudi Agadir.

\begin{tabular}{l|l|l}
\hline & \multicolumn{1}{|c|}{ MASONRY WALLS } & CEILING STRUCTURES \\
\hline & $\begin{array}{l}\text { instability for the lack of } \\
\text { verticality of walls }\end{array}$ & $\begin{array}{l}\text { failure by flexure due to } \\
\text { overload over the beams }\end{array}$ \\
\cline { 2 - 3 } $\begin{array}{l}\text { instability for excessive } \\
\text { thinning }\end{array}$ & $\begin{array}{l}\text { lack of homogeneity in the } \\
\text { load distribution for }\end{array}$ \\
CONSTRUCTION & $\begin{array}{l}\text { irregular geometry (curve) } \\
\text { of the joists }\end{array}$ \\
\cline { 2 - 3 } & $\begin{array}{l}\text { cracking for the lack of } \\
\text { interlocking joints in the } \\
\text { masonry sometimes due to } \\
\text { disparate stone sizes or lack } \\
\text { of mortar }\end{array}$ & failure by lack of support \\
\hline \multirow{2}{*}{$\begin{array}{l}\text { MAINTENANCE } \\
\text { PROBLEMS }\end{array}$} & $\begin{array}{l}\text { disaggregation by washing } \\
\text { out of the mortar }\end{array}$ & $\begin{array}{l}\text { fatigue resistance of the } \\
\text { beams due to insect attacks }\end{array}$ \\
\cline { 2 - 3 } $\begin{array}{l}\text { instability by mobilizing } \\
\text { pore pressures }\end{array}$ & $\begin{array}{l}\text { failure by shearing of the } \\
\text { wooden beams due to rot }\end{array}$ \\
\hline
\end{tabular}




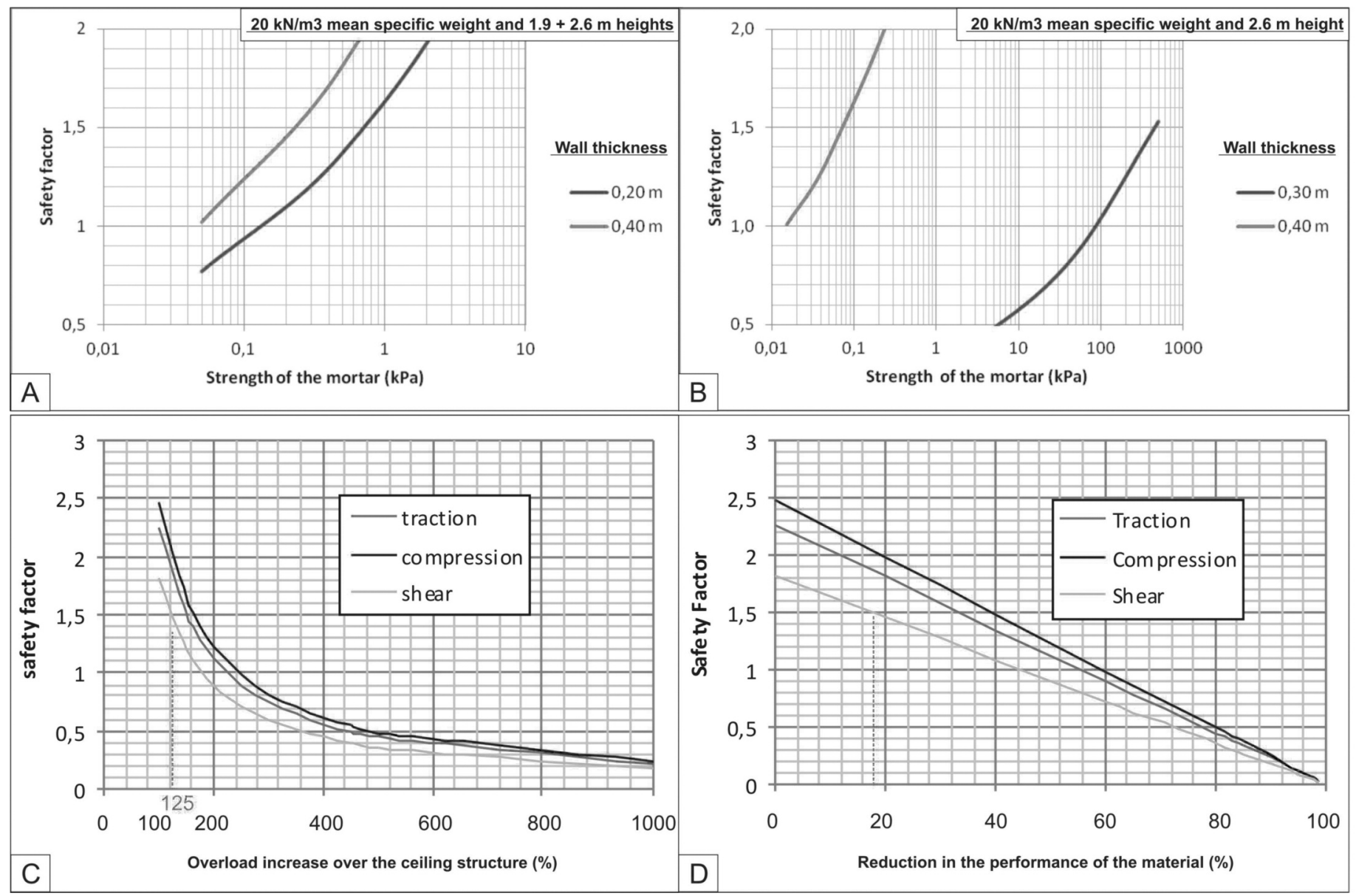

Fig. 10 - Wall safety-factor estimations for flexural buckling and ceiling structures with wooden joists and beams safety factor estimations for shearing, traction and compression stress: $A$ ) 2-height bridged masonry wall; $B$ ) 1-height free masonry wall; $C$ ) ceiling structure with increasing overload; $D$ ) ceiling structure when the performance of the wooden joists and beams is reduced.

safety factor falls below 1.5 , evidencing problems in case of seismicity or torrential rains. In this case, the safety factor would be below 1 with a total overload of about $180 \%$, provoking the collapse of the structure.

When a reduction in the performance of the wooden joists and beam was analyzed (flexural elastic modulus) by rot, insect attack, or material fatigue (fig. 10D), the behaviour in the three cases (traction, compression or share) proved different, with shearing clearly being the worst situation. In the case of shear, when a $20 \%$ reduction in performance occurs, the safety factor falls below 1.5. When the reduction is about $50 \%$, the safety factor is below 1 . The other two cases (compression and traction) show similar trends, the safety factor falling below 1.5 for a reduction of a $40 \%$ in the performance of the material, and below 1 for a $60 \%$ reduction. Therefore, the use of stone joists and beams is recommended due to their higher resistance. When not possible, a control of overload is required to avoid collapses of the ceiling structures made of wooden joists and beams.

\section{CONCLUSIONS}

- The Amtoudi Agadir is built directly on the bedrock (exploiting the irregularities of the basal surfaces to anchor the frame), using traditional techniques common in the region (both for the construction as well as for maintenance), and utilizing rocks for masonry, mortars of bad quality as binder (both coming from the surroundings), and wooden elements as joists, beams, lintels, doors, and windows.

- The architectonic structural elements of the agadir have been divided into load-bearing ones, working under a certain pressure (gravity and structural walls, buttresses and pillars) and supported ones, resting on the former and working by flexure under pressure (ceiling structures with joists and beams).

- The stones utilized for internal and external walls, buttresses, pillars and for ceiling structures are decimetric in size (rock fragments that can be lifted by one person) and were classified after the petrographic study into four petrofacies: wackestone/grainstone limestones (Petrofacies 1); claystone/siltstone (Petrofacies 2); arkosic sandstone arenites (Petrofacies 3); schist (Petrofacies 4).

- The Amtoudi Agadir is located in a subtropical dry climate characterized by great amplitude of daily temperature, wind action, very low precipitation rates, and lowaggressive rainfall chemistry. Biological degradations, chromatic alterations, failings-detachments-gaps, fracture-splitting, exfoliations-scaling, and erosions, were found to affect the quality of the rocks. Some recommendation for conservation and maintenance of the rocks problems of the Amtoudi Agadir have been previously 
proposed taking into account the constituent materials, their condition, their physical and chemical compatibility with the restoration products and the environment.

- In the case of the walls, buttresses and pillars, the main problems derive from excessively thin construction with a lack of interlocking of the rocks and the decrease proportion or quality of mortar joining the rocks due to washing (progressively outside-in). It is recommended to avoid thicknesses of less than $0.4 \mathrm{~m}$ 2-height walls and less than $0.3 \mathrm{~m}$ for 1-height walls. Moreover, when deterioration of the mortar is evident, repairs and maintenance are strongly recommended to avoid seriously compromising the stability of masonry walls.

Since there are no industrial materials in the region to realize the mortar, we can only perform suggestions to change the proportions of the same materials traditionally used, in order to obtain a mortar of better quality. The available components in the area, as exposed before, are: a natural material coming from the richest clay levels but with certain content in gravels, sands, and silts in which no treatment has been performed; the quicklime binder; and water. A ratio $1 / 3$ binder/clayed raw material is recommended. An equal amount by weight of lime and water should be used. A good mixing of the components is recommended to obtain more homogeneity of the mortar.

- The ceiling structures depend largely on the joists and beams. Stone elements are recommended but wooden joists and beams (palm and argan mainly) were more commonly used in the agadir. Quality loss of wooden elements derives from fatigue, rot or insect attacks seriously imperilling the safety of the ceiling structures. Therefore, repairs and maintenance are also highly advisable in order to replace wooden joists, beams, and lintels when those show the initial damage symptoms (flexion), in order to avoid the shearing of the wooden elements and the collapse of the ceiling structures.

- The Amtoudi Agadir is a key case of a fortified building that materializes historical culture and tradition of the southern Moroccan population. It therefore constitutes an important heritage that deserves particular attention, firstly to show it to national and foreign tourists and then to take steps in order to minimize its degradation. For the management and protection of this historical site, the following considerations and recommendations have resulted from this multidisciplinary study: (1) data and considerations presented in this paper constitute a solid starting point for appropriate and urgent solutions that must be implemented; (2) It is strongly advised to immediately place this monument under the care of the Moroccan Ministry of Culture for the maximum protection of national cultural heritage since it represents a testimony of the birth of the nation of Morocco; (3) A qualified scientific approach will enable an evaluation of the various aspects of degradation and risk of the structure. Appropriate and urgent solutions, therefore, need to be found and implemented; (4) It is strongly recommend to establish a team of specialists in different fields as archaeometry, geology, geotechnics, architecture, archaeology, and restoration in order to take inventory and diagnose all southern Moroccan agadirs; (5) Furthermore, the promotion of a cultural and natural tourism to visit these southern Moroccan agadirs offers a clear economic benefit for the population of these remote areas, and thus it would also be advisable to regulate visits to control the large flow of visitors that could contribute to the further decay of this very valuable cultural site.

\section{ACKNOWLEDGMENTS}

This research was supported by Urbino University found (Resp. F. Guerrera); by CGL2011-30153-CO2-02 and CGL2012-32169 research project (Spanish Ministry of Education and Science) and by Research Groups and projects of the "Generalitat Valenciana" from Alicante University (CTMA-IGA). We would also like to thank the Research Unit associated with CNRST (URAC 46), Scientific Institute and Mohammed V University, Morocco, for logistical support and equipment for fieldwork and sampling. The authors are very grateful to a native speaker (David Nesbitt) for improving the English version of the manuscript.

\section{REFERENCES}

AA.V.V. (1986) - Preventive measures during excavations and Site protection. Atti della conferenza di Ghent, 6-8 November 1985 , ICCROM, Roma.

Alcalá F.J., Cantón Y., Contreras S., Were A., Serrano-Ortiz P. Puigdefábregas J., Solé-Benet A., Custodio E. \& Domingo F. (2011) - Diffuse and concentrated recharge evaluation using physical and tracer techniques: results from a semiarid carbonate massif aquifer in southeast Spain. Environmental Earth Sciences, 63, 541-557.

AlCALÁ F.J. \& CUSTODIO E. (2015) - Natural uncertainty of spatial average aquifer recharge through atmospheric chloride mass balance in continental Spain. Journal of Hydrology, 524, 642-661.

Alcalá F.J., Martínez-VAlderrama J., Robles-Marín P., GuerRERA F., MARTín-Martín M., RAFFAElli G., TEJERA DE LEÓN J. \& ASEBRIY L. (2015) - A hydrological-economic model for sustainable groundwater use in sparse-data drylands: Application to the Amtoudi Oasis in southern Morocco, northern Sahara. Science of the Total Environment, 537, 309-322.

Amadori M.L., Mecchi A.M., Monte M., Musco S. \& Salvatori A (1989) - La conoscenza dei materiali e delle strutture per un progetto di restauro nel Parco Archeologico di Gabii. In: Proceedings of Il cantiere della Conoscenza, il Cantiere del Restauro. Bressanone, 295-308

ANDREws G. (1991) - The management of Archaeological Projects. In Managing Archeology, Routledge 2005, 184-203.

ARORA V.K. (2002) - The use of the aridity index to assess climate change effect on annual runoff. Journal of Hydrology, 265, 164-177.

BANTA L., CHENG K. \& ZANIEWSKI J. (2003) - Estimation of limestone particle mass from 2D images. Power Technol., 132, 184-189.

BERNARDi A. (2003) - Conservare opere d'arte. Il microclima negli ambienti museali. Il Prato Ed., Collana Le Pleiadi, Padova, 9.

Boe (2006) - Código Técnico de Edificación. Real Decreto 314/2006, 17 marzo, Parte 2. DB SE-AE (Seguridad Estructural Acciones en la Edificación) y DB-SE-F (Seguridad Estructural Fábrica). Boletín Oficial del Estado, 74, 11816-11831.

BorN K., FINK A.H. \& PAETH H. (2008) - Dry and wet periods in the northwestern Maghreb for present day and future climate conditions. Meteorologische Zeitschrift, 17 (5), 533-551.

BRADley S.M. \& Middleton P.M. (1988) - A study of the deterioration of Egyptian limestone sculpture. Journal of the American Institute for Conservation, 27 (2), 64-86.

Burkhard M., Caritg S., Helg U., Robert-Charrue C. \& SoulaiMANI A. (2006) - Tectonics of the Anti-Atlas of Morocco. C.R. Géoscience, 338, 11-24.

CAMUfFo D. (1992) - Acid in and deterioration of monuments how old is the phenomenon?. Atmospheric Environment, 26B (2), 241-247.

Choubert G. (1963) - Histoire géologique du Précambrien de l'AntiAtlas. Notes et Mém. Serv. géol. Maroc, 162, pp.

COOKE R.U. (1979) - Laboratory simulation of salt weathering processes in arid environments. Earth Surface Processes, 4, 347-359.

ENNIH N. \& LIÉgeOIS J.P. (2001) - The Moroccan Anti-Atlas: The West African Craton passive margin with limited Pan-African activity. Implications for the northern limit of the craton. Precambrian Research, 112, 289-302. 
Esper J., Frank D., Buentgen U., Verstege A. \& Luterbacher J. (2007) - Long-term drought severity variations in Morocco. Geophysical Research Letters, 34, L17702. doi: 10.1029/2007 GL030844.

FERNLUND J.M.R. (2005) - Image analysis method for determining 3D size distribution of coarse aggregates. Bull. Eng. Geol. Environ, 64, 19-166.

Gasouet D., EnNih N., Liégeois J.P., Soulaimani A. \& Michard A. (2008) - The Pan-African Belt. In: Michard A., Saddiqi O., Chalouan A. \& de Lamotte F. (eds.), Continental evolution: The Geology of Morocco, Lecture Notes Earth Sci., 116, SpringerVerlag, Berlin, Heidelberg, 33-64.

Gazzi P., Zuffa G.G., Gandolfi G. \& Paganelli L. (1973) - Provenienza e dispersione litoranea delle sabbie delle spiagge adriatiche fra le foci dell'Isonzo e del Foglia: inquadramento regionale. Mem. Soc. Geol. It., 12, 1-37.

Gere J.M. (2004) - Mechanic of materials. Thomson Learning, Inc., Sixth Edition, 964 pp.

Gorgoni C., Amadori M.L., Lazzarini L. \& Pallante P. (1993) Risultati dell'indagine micropaleontologica, minero-petrografica, e geochimica preliminare sui materiali lapidei (calcari e marmi) dell'insediamento greco di Selinunte. In: AA.VV., Tecnologie moderne per la conservazione dei Beni culturali - Selinunte 1, Roma, C.N.R., 33-59.

Khiri F., Ezaidi A. \& KabBachi K. (2004) - Dust deposits in SoussMassa basin, South-West of Morocco: granulometrical, mineralogical and geochemical characterisation. Journal of African Earth Sciences, 39, 459-464.

KumARA G.H.A., HAYANO K. \& OgIWARA K. (2012) - Image analysis techniques on evaluation of particle size distribution of gravel. Intern. J. of Geomate, 3 (1-5), 290-297.

LAZZARINI L. \& LAURENZI TABASSO M. (1986) - Il restauro della pietra, CEDAM Ed., Padova. pp. 24, 27, 58-60, 72-75.

La Iglesia A., Garcõa del CuRa M.A. \& Ordoñez S. (1994) - The physicochemical weathering of monumental dolostones, granites and limestones: dimension stones of the Cathedral of Toledo (Spain). Science of the Total Environment, 152, 179-188.

Matović B., ERić S., SRećKović-Batoćanin D., Colomban P. \& KREMENOVIĆ A. (2014) - The influence of building materials on salt formation in rural environments. Environmental Earth Sciences, 72, 1939-1951.
Naidoo D.D., Bloomer S.H., Saquaque A. \& HefFeran K.P. (1991) Geochemistry and significance of metavolcanic rocks from Bou AzzerEl Graara ophiolite (Morocco). Precambrian Research, 53, 79-97.

NAJI S. (2003) - Greniers collectifs de l'Atlas. Patrimoines du Sud marocain. Editions Edisud et Editions La croisée des Chemins, Casablanca, Maroc, ISBN 9981-896-89-6, 299 pp.

Robles-Marín P., Guerrera F., Martín-Martín M., RafFaelli G., Alcalá F.J., Tejera de León J., Cherkaoui T.E., Asebriy L., El AMrani I.E. \& Moliner-Aznar S. (2015) - Geological risk assessment of Amtoudi Agadir in southern Morocco: a key case for sustainable cultural heritage. Natural Hazard, 75, 415-440.

Sebti S., Saddioi O., El Haimer F.Z., Michard A., Ruiz G., BouSOUET R., BAIDDER L. \& FRIZON DE LAMOTTE D. (2009) - Vertical movements at the fringe of the West African Craton: First zircon fission track datings from the Anti-Atlas. Precambrian basement, Morocco. C.R. Géosci., 341, 71-77.

SOULAIMANI A. (1998) - Interactions socle/couverture dans l'Anti-Atlas occidental (Maroc): rifting fini-proterozoïque et orogenèse hercynienne. Thèse Doct., Université Marrakech, Maroc, 215 pp.

Soulaimani A. \& Burkhard M. (2008) - The Anti-Atlas chain (Morocco): the southern margin of the Variscan belt along the edge of the West African Craton. In: N. Ennih, J.-P. Liégeois (eds.), The boundaries of the West African Craton, Geol. Soc. London Spec. Publ., 297, 429-448.

THORnBush M.J. \& VILEs H.A. (2008) - Photographic monitoring of soiling and decay of roadside walls in Oxford, England. Environmental Geology, 56 (3-4), 777-787.

Thornbush M.J. (2013) - Photogeomorphological studies of Oxford stone- a review. Landform Analysis, 22, 111-116.

THORNBUSH M.J. (2014) - Measuring surface roughness through the use of digital photography and image processing. Intern. Journal of Geosciences, 5, 540-554.

UNE 22950-1 (1990) - Mechanical properties of rocks. Strength determination tests. Part 1. Uniaxial compressive strength. $4 \mathrm{pp}$.

UNE 22950-3 (1990) - Mechanical properties of rocks. Strenght determination tests. Part 3. Modules of elasticity (Young) and Poisson's ratio determination. $10 \mathrm{pp}$.

UNE-EN 1936 (2007) - Natural stone test methods. Determination of real density and apparent density, and of total and open porosity. $14 \mathrm{pp}$.

Manuscript received 24 May 2015; accepted 23 July 2015; editorial responsability and handling by M. Mazzucchelli. 